\title{
LA POSIBILIDAD DE LIQUIDAR UNILATERALMENTE LOS CONTRATOS INTERADMINISTRATIVOS
}

Presentado por:

ROBERTO ANDRÉS BROCHERO MONTERO

Tutor:

LEONARDO ÁLVAREZ CASALLAS

UNIVERSIDAD SANTO TOMÁS DE AQUINO

FACULTAD DE DERECHO - MAESTRÍA EN DERECHO CONTRACTUAL PÚBLICO Y PRIVADO COLOMBIA

2017 
Primero darle gracias a Dios, A mis padres que lo dieron todo por mi y especialmente a mi madre que me acompaña siempre. A mis hermanos siempre incondicionales, A Bibiana León, mi compañera de vida y sobretodo amiga, por su paciencia, la espera y porque siempre ha creído en mi y me ha apoyado en todos los momentos, sin pedir nada a cambio 


\section{TABLA DE CONTENIDO}

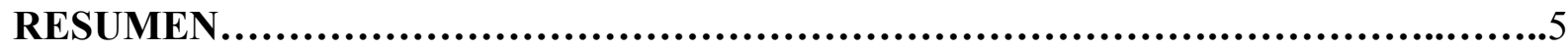

ABSTRACT .................................................................................

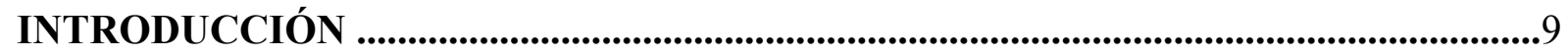

CAPÍTULO I - Desarrollo normativo de los Contratos Interadministrativos en

Colombia y el Ecuador y la Evolución normativa de las cláusulas excepcionales en

Colombia

1.1 Evolución normativa y diferencias entre Convenio Interadministrativo y Contrato Interadministrativo.

1.2 Concepto y Diferencias entre el Convenio y Contrato

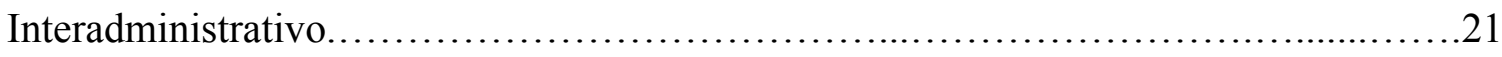

1.3 Contrato interadministrativo como instrumento jurídico de la Administración Pública

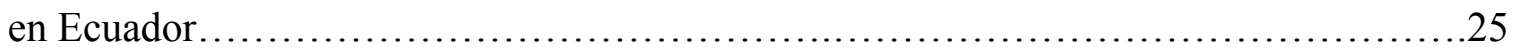

1.4 De las cláusulas excepcionales fijadas en los contratos estatales en Colombia. , n

1.5 Clasificación de las cláusulas excepcionales en

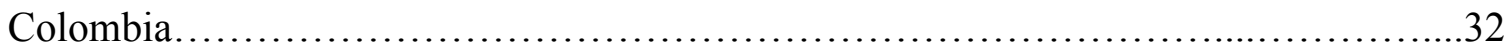

1.5.1 Interpretación Unilateral del Contrato Estatal.........................33

1.5.2 Modificación Unilateral del Contrato Estatal................. 34

1.5.3 Terminación Unilateral del Contrato Estatal.................. 35

1.5.4 Caducidad del Contrato Estatal.............................41

1.5.5 Reversión................................................44 
CAPÍTULO II - Desarrollo normativo, doctrinal, jurisprudencial y derecho comparado (Ecuador) de la liquidación unilateral en los contratos interadministrativos.

2.1 De la liquidación por mutuo acuerdo y liquidación

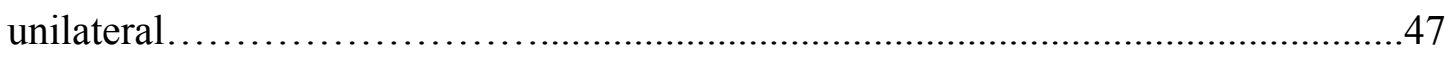

2.2 Algunos aspectos relevantes de la liquidación unilateral en los contratos

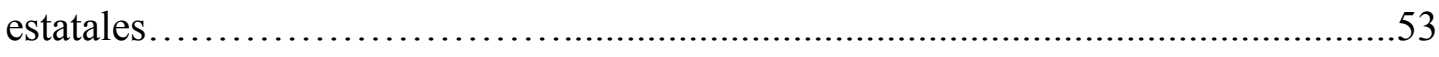

2.3 Análisis Legislativo comparado de liquidaciones unilaterales en los contratos interadministrativos en la República de Ecuador....................................56

2.4 Desarrollo jurisprudencial de la liquidación unilateral de contratos interadministrativos celebrados desde el año

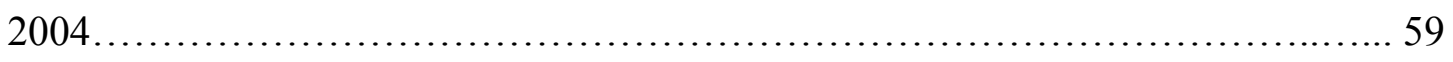

2.5 Casos de liquidaciones de contratos interadministrativos, con cláusulas y sin ellas, desde $\quad$ el $\quad$ año $\quad 2014 \quad$ al $\quad 2017$

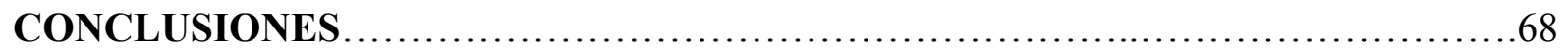




\section{RESUMEN}

La liquidación unilateral en los contratos estatales es una herramienta jurídica reglada en el estatuto de contratación colombiano, para que en determinadas circunstancias pueda ser empleada por las entidades estatales, con la finalidad de finiquitar y tomar decisiones respecto de los resultados y las obligaciones contraídas en un contrato, sin necesidad de contar con la voluntad o con el consentimiento de la contraparte.

Para el caso concreto de la presente investigación, las liquidaciones unilaterales en los contratos interadministrativos ha sido un instrumento jurídico que el legislador colombiano no reguló de forma clara y expresa si puede o no darse su aplicación. Sin embargo el Consejo de Estado, máximo tribunal de lo contencioso administrativo, profirió algunas sentencias con posiciones que resultan ser disímiles y generan controversia, por cuanto consideró en una decisión judicial la prohibición de liquidar unilateralmente los contratos interadministrativos equiparando la interpretación de potestad unilateral a la de una cláusula exorbitante.

Sin embargo, en otra sentencia proferida por el Consejo de Estado, señaló que las cláusulas exorbitantes como prerrogativas de las entidades públicas son para mitigar situaciones que afectan la prestación del servicio y, por consiguiente, el interés público, y solo se circunscriben a las taxativamente señaladas en la Ley $\mathrm{N}^{\circ} 80$, 1993, es decir, las consagradas en los artículos 14 al 19 del estatuto de contratación.

En consecuencia, al no tener una postura pacífica en la aplicación de las normas que regulan la liquidación unilateral en los contratos interadministrativos y la incertidumbre que genera no contar con una herramienta para finiquitar este tipo de contratos unilateralmente, el trabajo de investigación buscó resolver si la figura de la liquidación unilateral en la contratación pública es una cláusula o facultad excepcional de la administración, si se le aplica la prohibición 
de su aplicación en los contratos interadministrativos, teniendo en cuenta las posturas legales adoptadas por el legislador, doctrinales, jurisprudenciales y en conclusión se puede entender que la liquidación unilateral en los contratos interadministrativos es posible en la medida en que no es una potestad exorbitante, ni un poder unilateral caprichoso de la administración, aun cuando se está entre sujetos contractuales iguales, sino que se circunscribe a una herramienta jurídica post-contractual que tiene como fin hacer un balance y un ajuste de cuentas en la ejecución del contrato estatal.

Palabras Claves: Contrato Estatal, Contrato Interadministrativo, Convenio Interadministrativo, Liquidación Unilateral, Cláusulas Excepcionales. 


\begin{abstract}
The unilateral liquidation of state contracts is a legal tool governed by the Colombian contracting statute, so that in certain circumstances it may be used by state entities, with the purpose of finalizing and making decisions regarding the results and obligations contracted in a Contract, without the need for the will or with the consent of the counterparty.

For the specific case of the present investigation, unilateral settlements in interadministratives contracts has been a legal instrument that the Colombian legislator does not regulate clearly and expresses whether or not it can be applied. However, the Council of State, the highest court for administrative litigation, issued a number of judgments with positions that are dissimilar and controversial, since I consider in a judicial decision the prohibition of unilaterally liquidating inter-administrative contracts by equating the unilateral interpretation of power of an exorbitant clause.
\end{abstract}

However, in another ruling issued by the Council of State, I point out that exorbitant clauses as prerogatives of public entities are to mitigate situations that affect the provision of the service and, therefore, the public interest, and are limited only to those specifically mentioned at No. 80,1993 , the law that is enshrined in articles 14 to 19 of the statute of contracting.

Consequently, by not having a peaceful position in the application of the rules governing unilateral settlement in inter-administrative contracts and the uncertainty generated by not having a tool to finalize this type of contracts unilaterally, the research work sought to resolve if the Unilateral liquidation in public procurement is a clause or exceptional authority of the administration, if it is applied the prohibition of its application in inter-administrative contracts, taking into account the legal positions adopted by the legislature, doctrinal, jurisprudential and in conclusion It can be understood that unilateral liquidation in inter- 
administrative contracts is possible insofar as it is neither an exorbitant power not a capricious unilateral power of administration, even though it is between equal contractual subjects, but is confined to a legal tool post -contractual that in order to make a balance and an adjustment of accounts in the execution of the state contract.

Key Words: State Contract, Inter-administrative Contract, Inter-Administrative Agreement, Unilateral Settlement, Exceptional Clauses. 


\section{INTRODUCCIÓN}

En la legislación colombiana, en la doctrina como en la jurisprudencia, no hay una postura pacífica de la aplicabilidad de la liquidación unilateral en los contratos interadministrativos. Considerando que se trata de una prohibición, lo contemplado en el parágrafo del artículo 14 de la Ley $\mathrm{N}^{\circ} 80,1993$, debe ser interpretado en sentido restrictivo, lo cual implica que sólo debe estar limitado a las situaciones reguladas en dicha norma (Santos, 2008).

No obstante lo anterior, en los contratos interadministrativos al tener una relación de contratante y contratista como sujetos de derecho público, en un plano de igualdad de la administración, se afirma que existe un impedimento a la hora de las imposiciones unilaterales en esta tipo de contratos, en el que la contraparte también es el Estado.

Bajo ese panorama, el (Consejo de Estado, expediente 25.154, 2004), ha manifestado que lo contemplado en el artículo 14 de la Ley $\mathrm{N}^{\circ} 80,1993$, se hace extensivo también a los artículos 60 y 61 de la misma ley.

Es decir, el parágrafo del artículo 14 de la Ley $\mathrm{N}^{\circ} 80$, 1993, sobre los medios que pueden utilizar los entes estatales para el cumplimiento del objeto contractual, señala acerca de los contratos interadministrativos lo siguiente: “...se prescindirá de la utilización de las cláusulas o estipulaciones excepcionales...".

A su vez relaciona como cláusulas excepcionales al derecho común las de terminación, interpretación y modificación unilaterales y de caducidad.

En el artículo $60^{1}$ de la Ley 80,1993 , que describe la ocurrencia y contenido de la liquidación del contrato estatal en Colombia, desarrolla algunos parámetros reglados que debe

\footnotetext{
${ }^{1}$ En los contratos de tracto sucesivo, aquéllos cuya ejecución o cumplimiento se prolongue en el tiempo y los demás lo requieran, serán En el artículo 61 de la Ley $\mathrm{N}^{\circ} 80,1993$, sobre la liquidación unilateral, se refiere lo siguiente: “...si el contratista no se presenta a la liquidación o las partes no llegan a acuerdo sobre el contenido de la misma, será aplicada directa y unilateralmente por la entidad y se adoptará por acto administrativo motivado susceptible del recurso de reposición...".
} 
tener en cuenta el operador jurídico en el momento de la utilización del citado instrumento jurídico.

Así mismo, ya para las situaciones en las que la entidad pública se encuentre abocada a la utilización de una liquidación unilateral del contrato estatal, el legislador colombiano definió en el artículo 61 de la Ley $\mathrm{N}^{\circ}$ 80, 1993, las circunstancias de modo, tiempo y lugar que facultan a la administración para dar por terminado definitivamente el vínculo derivado del contrato.

De lo anterior, para el Consejo de Estado, la integración normativa hecha con respecto a las tres normas ${ }^{2}$, permite inferir que la facultad del Estado para liquidar unilateralmente un contrato, en la regla general, se puede llevar a cabo cuando un particular suscribe un contrato con una entidad. En este caso específico, el poder que ejerce la entidad estatal de imponer coactivamente su voluntad sobre el contratista, durante la ejecución o liquidación del contrato, y en el deber de éste último de cumplir inmediatamente las obligaciones que le sean impuestas, sin perjuicio del derecho que le reconoce la ley de solicitar ante la jurisdicción de lo contencioso administrativo la nulidad de los actos y la reparación de los daños antijurídicos: "Tal facultad administrativa, otorga a una entidad pública, y únicamente frente a su colaborador privado, lo que permite inferir que no aplica para el contrato interadministrativo, en el cual ambas partes son agentes públicos, pues ambos representan la administración pública gestora del interés general y, por lo tanto, no imperan frente a éstas, los poderes coactivos, como así lo informa indirectamente el artículo 14 de la Ley $\mathrm{N}^{\circ}$ 80, 1993, que si bien alude a cláusulas excepcionales, ontológicamente se erige en canon ilustrativo de la prohibición del ejercicio de poderes unilaterales del Estado contratante respecto del Estado contratista" (Consejo de Estado, expediente 25.154. 2004).

Por otra parte, también se ha señalado, que si la norma es clara en consagrar una

\footnotetext{
${ }^{2}$ Artículos 14, 60 y 61 de la Ley N 80, 1993.
} 
prohibición para incluir las cláusulas excepcionales, previstas en el mismo artículo 14 de la Ley $\mathrm{N}^{\circ} 80,1993$, se aplicará en todo su sentido tal como lo ordena el artículo 8 de la Ley $\mathrm{N}^{\circ} 153$, 1993 y no como lo plantea el Consejo de Estado en la sentencia referida, donde habla de la integración normativa, pues en este caso no hay lugar a dicha apreciación, en la medida en que la norma señala exactamente cómo debe ser su aplicación. En esos términos no hay lugar a aplicar la analogía en los demás eventos en los cuales existe la posibilidad de utilizar facultades exorbitantes (Matallana, 2013).

Teniendo en cuenta lo anterior, se plantea la siguiente hipótesis: La aplicación de la liquidación unilateral en el contrato interadministrativo es procedente, en la medida que la prohibición de pactar cláusulas excepcionales en los convenios o contratos interadministrativos es referida exclusivamente a las cláusulas excepcionales contenidas en el artículo 14 de la Ley $\mathrm{N}^{\circ} 80,1993$, relacionadas con la terminación, interpretación y modificación unilaterales, de sometimiento a las leyes nacionales y de caducidad.

Por lo anteriormente referido como objetivo general es imperativo establecer el alcance de la aplicación de las normas que regulan la liquidación unilateral en los contratos interadministrativos, esto en la facultad de liquidar unilateralmente un contrato interadministrativo. El objetivo se desarrollará específicamente en la medida en que se indague i) si la figura de la liquidación unilateral en la contratación pública es una cláusula o facultad excepcional de la administración, si se aplica la prohibición de su aplicación en los contratos interadministrativos, teniendo en cuenta las posturas legales adoptadas por el legislador, doctrinales, jurisprudenciales por parte del Consejo de Estado; ii) determinar si en el contrato interadministrativo, regido por la normatividad del Estatuto General de la Contratación Pública, es permisible el ejercicio de esta potestad por parte de la entidad pública contratante. 
En definitiva el asunto a resolver requiere, como presupuesto, definir el carácter excepcional de la liquidación unilateral y si al serlo se rige de conformidad con lo regulado para las potestades unilaterales descritas en el artículo 14 de la Ley $\mathrm{N}^{\circ} 80,1993$ o si por el contrario, encuentra su regulación en lo contemplado en el artículo 61 de la misma ley.

En virtud de lo anterior, la metodología aplicada, fue la comparación jurídica, ilustrada por (Merryman, 2011) y (Tamayo, 2007). En la primera fase se recolecta información de los institutos jurídicos que tuvieron relación con la pregunta problema del trabajo invetigación. En una segunda fase, por medio de la documentación recaudada, y el análisis de aproximación jurisprudencial de las dos posturas planteadas por el Consejo de Estado, se identifica y se desarrolla un marco teórico conceptual, que permita construir una visión analítica de todo el sistema jurídico, que aporte a los objetivos planteados. Finalmente en la tercera fase, se concluye, con la evaluación normativa, jurisprudencial y doctrinaria los efectos de la aplicación de la liquidación unilateral en los contratos interadministrativos.

Para completar este análisis la presente investigación se divide en dos capítulos. En el primero se presenta una aproximación conceptual al contrato y al convenio interadministrativo, así como sus diferencias y similitudes; características del contrato interadministrativo reglado en la legislación ecuatoriana, respecto al reglado en Colombia, y un repaso del desarrollo normativo y doctrinal de las cláusulas exorbitantes en Colombia.

En el segundo capítulo se concreta el carácter de excepcionalidad de las liquidaciones unilaterales en los contratos interadministrativos, para establecer si es o no posible la aplicación del citado instrumento en los términos del artículo 14 de la Ley $\mathrm{N}^{\circ} 80,1993$. Allí se analizan algunas posturas jurisprudenciales del Consejo de Estado desde el año 2004 a la fecha en la que se evidencian posturas diferentes, que suscita el problema jurídico del trabajo de investigación. 
Así mismo se lleva a cabo un análisis legislativo comparado de liquidaciones unilaterales en los contratos interadministrativos en la República de Ecuador. A renglón seguido se analizan algunos casos presentados de forma aleatoria en entidades del orden nacional, entre el 2014 a 2017, relacionados con liquidaciones unilaterales en contratos interadministrativos, en los que se evidencian las diferentes posturas tomadas por las entidades públicas al no tener en la legislación colombiana una norma clara y expresa sobre la utilización de la citada figura. En las conclusiones se demuestra a partir de la tesis planteada con relación al tratamiento de la liquidación unilateral, que no son comparables con las potestades excepcionales establecidas en el artículo 14 de la Ley $\mathrm{N}^{\circ} 80,1993$.

La pertinencia del derecho comparado, concretamente el aporte de la legislación ecuatoriana sobre el instituto jurídico que es objeto de estudio en este trabajo de investigación, en una dimensión comparativa a la luz del método de la escuela alemana juscomparatista (Carvajal, 2015), permite concluir que la citada legislación, contribuye en la solución del problema jurídico planteado, en la medida que la aplicación de una norma general al momento de liquidar unilateralmente un contrato estatal, se rige por el mismo procedimiento para el caso de los contratos interadministrativos, sin perjuicio que al mismo nivel se encuentren dos entidades públicas.

Así mismo en el desarrollo de los acápites relacionados con la legislación ecuatoriana, se hace una descripción sobre las instituciones jurídicas vinculadas con la comparación, se lleva a cabo una breve reseña del fundamento normativo y doctrinal de los contratos estatales, en concreto, la regulación de los contratos interadministrativos y las liquidaciones de los contratos estatales en el Ecuador; se exponen algunas semejanzas entre las dos legislaciones, tales como la aplicación de la modalidad de contratación directa y el carácter excepcional en esta tipología de 
contratos, se plantean algunas diferencias como por ejemplo el concepto de lo público en los contratos interadministrativos en el derecho ecuatoriano, en la medida que trasciende la frontera nacional, pues se consideran como contratistas públicos no solo a las empresas públicas ecuatorianas sino también a aquellas de naturaleza pública que pertenezcan a la comunidad internacional. Otra de las diferencias como la obligatoriedad que determina la legislación ecuatoriana de una vez se haya terminado el contrato, se lleve a cabo la recepción y liquidación parcial o definitiva dependiendo del contrato y las circunstancias, sin perjuicio de que en el evento de que el funcionario se abstenga de liquidar el contrato, podría ser sancionado por el Consejo de la Judicatura, y por último la reglamentación del mismo procedimiento frente al contratista público y privado, para administrar, terminar, recibir y liquidar contratos. 


\section{CAPÍTULO I}

\section{Desarrollo normativo de los Contratos Interadministrativos en Colombia y Ecuador y \\ la Evolución normativa de las cláusulas excepcionales en Colombia}

\subsection{Evolución normativa y diferencias entre Convenio Interadministrativo y Contrato Interadministrativo}

A partir de la obligación que recae sobre el Estado colombiano, de satisfacer las necesidades de los ciudadanos, la responsabilidad de proveer bienes y servicios, de conformidad con la estructura organizacional y misional de las entidades públicas, quienes se encuentran revestidas de funciones y de presupuesto económico, para cumplir con los fines que se la ha encomendado, el legislador colombiano ha dispuesto instrumentos y procedimientos en materia de contratación para el cumplimiento de esos fines del Estado (Constitución Política Colombiana, 1991) ${ }^{3}$.

Entre las formas como actúa la administración pública para cumplir con los fines del Estado existen diferentes modelos asociativos articulados a través de actores, que no son solamente instituciones públicas, cuya labor podría interpretarse como una actividad monopolística del Estado, sino que tiene la posibilidad de valerse de múltiples facetas como el modelo de asociación entre entidades públicas y privadas que permite a la administración lograr, con un costo menor, los objetivos asignados (Chevallier, 2003, citado por Pierre, 2010).

De lo anterior se desprende que la administración pública debe velar por la prestación de servicios de forma permanente y adecuada hacia toda la ciudadanía que se encuentra dentro del Estado colombiano, de ahí la importancia de contar con diferentes herramientas jurídicas que

\footnotetext{
${ }^{3}$ Artículo 2. Son fines esenciales del Estado: servir a la comunidad, promover la prosperidad general y garantizar la efectividad de los principios, derechos y deberes consagrados en la Constitución; facilitar la participación de todos en las decisiones que los afectan y en la vida económica, política, administrativa y cultural de la Nación; defender la independencia nacional, mantener la integridad territorial y asegurar la convivencia pacífica y la vigencia de un orden justo
} 
facultan a los funcionarios o, mejor dicho, a los operadores de la administración, para que escojan, de conformidad con las reglas previstas en el ordenamiento jurídico, entre diversos mecanismos de asociación y de colaboración que permitan cumplir con los propósitos para los cuales fueron concebidas dentro del mundo de la gestión pública.

Entre las reglas establecidas para contratar con el Estado (Benavides, 2004), el legislador colombiano estableció en el estatuto de contratación, la Ley $N^{\circ} 80,1993^{4}$, diferentes tipos de procesos de selección con los que cuenta la administración pública. Entre otros estableció, por regla general, dos procesos de selección: la licitación pública y el concurso de méritos; excepcionalmente y para determinadas situaciones estableció la contratación directa. Posteriormente, con la llegada de la Ley $\mathrm{N}^{\circ} 1150,2007$, aumentó y modificó las herramientas con las que el operador podría contar para adelantar procesos de contratación para lo que introdujo en el ordenamiento jurídico dos procesos exceptivos: la selección abreviada y el concurso de méritos, que reemplazaron a los concursos públicos regulados por la Ley $\mathrm{N}^{\circ} 80$, 1993. Hasta este momento se mantuvo la contratación directa regulada por la Ley 1450 de 2011, que da lugar al Plan Nacional de Desarrollo 2010 - 2014 y que en su artículo 274, subrogado por el artículo 94 de la Ley 1474, 2011, creó la contratación de mínima cuantía, debido a la derogatoria de la norma pertinente de la Ley $\mathrm{N}^{\circ}$ 80, 1993 por parte de la Ley $\mathrm{N}^{\circ} 1150,2007 \mathrm{y}$ al olvido de esta en la regulación de la materia (Dávila, 2016).

\footnotetext{
${ }^{4}$ Artículo 3. De los Fines de la Contratación Estatal. Los servidores públicos tendrán en consideración que al celebrar contratos y con la ejecución de los mismos, las entidades buscan el cumplimiento de los fines estatales, la continua y eficiente prestación de los servicios públicos y la efectividad de los derechos e intereses de los administrados que colaboran con ellas en la consecución de dichos fines. Los particulares, por su parte, tendrán en cuenta al celebrar y ejecutar contratos con las entidades estatales que, además de la obtención de utilidades, cuya protección garantiza el Estado, colaboran con ellas en el logro de sus fines y cumplen una función social que, como tal, implica obligaciones.
} 
En el ámbito del derecho administrativo colombiano la transformación y el desarrollo de nuevas herramientas jurídicas empleadas por las entidades públicas para el cumplimiento de los intereses colectivos, como las modalidades de selección de contratista con las que cuenta la administración pública, se encuentran debidamente reguladas para diferentes situaciones en las que el Estado deba contratar. Este conjunto de normas, que permite cumplir con la función social que tiene el Estado, que se traduce en la garantía de derechos ciudadanos, el acceso y la retribución efectiva de bienes y servicios a toda la población en general. Al respecto (Dávila Vinuenza, 2016, p. 31) señala que en la celebración de un contrato estatal, el interés público debe estar presente, así sea de manera directa o mediata. La contratación es tan solo un instrumento de la gestión estatal para el cumplimiento de sus cometidos estatales y por ende es necesario que persiga un objetivo jurídico (Ospina Fernández, 1994).

Los cambios y la evolución del derecho en general, como instrumento para satisfacer los intereses de toda la población, han permitido que se desarrolle la teoría del contrato administrativo, y así mismo, se determine como un área específica del derecho que regula el vínculo jurídico y las relaciones entre entidades públicas persé, y entre entidades públicas y los particulares, (Gibert 2010, p.65) señala que el riesgo de asimilar el managment de las empresas (privadas) a la gestión pública, se presenta en que son dos universos que descansan sobre lógicas diferentes: las relaciones esenciales de una empresa privada con su ámbito, se caracterizan por el intercambio, el contrato, el acuerdo de voluntades mientras que las administraciones públicas captan de manera unilateral unos recursos, los redistribuyen y ofrecen prestación sin contraparte, prohíben o, al contrario obligan hacer cosas y más generalmente, reglamentan comportamientos (Mutis Vanegas y Quintero Múnera, 2000). 
Para el Doctrinante (De la Puente y Lavalle, 1998) define que "el contrato es administrativo por razón de su objeto cuando tratándose de una prestación a cargo del contratante (contrato de colaboración) dicha prestación se relaciona directa e inmediatamente, con alguna de las funciones esenciales o específicas del estado, con los "fines del estado"

Entre las primeras teorías relacionadas con este tipo de contratos, se desarrolla en la doctrina francesa; el tratadista (Diez, 1965), señaló que en los años cincuenta la jurisprudencia francesa exigía dos condiciones para que el contrato de la administración pública fuera considerado un contrato administrativo, debía reunir dos condiciones, la primera que se tratara de la organización y funcionamiento de un servicio público, y en segundo lugar que existiera una cláusula exorbitante del derecho privado.

Teniendo en cuenta lo anterior, en el marco del derecho se cuenta con instrumentos jurídicos como los convenios interadministrativos que fueron reglamentados y adoptados, dentro del ordenamiento legal colombiano, que empiezan su historia con el estatuto anterior de contratación administrativa, contenido en el Decreto Ley $\mathrm{N}^{\circ} 222,1983 .^{5}$

Con la creación del instrumento jurídico citado, se posibilitó, en la administración pública, la asociación entre dos o más entidades del Estado con el propósito de desarrollar una dinámica de integración, colaboración y armonización que persiga juntar esfuerzos, que tengan por objeto satisfacer actividades grupales e individuales propias de la administración de acuerdo con sus competencias.

En el inicio de este análisis se constató que en el artículo 16, del estatuto anterior de contratación colombiano, Decreto Ley $\mathrm{N}^{\circ} 222$, 1983, se señalan los tipos de contrato administrativo de carácter público y los contratos administrativos de carácter privado que la

\footnotetext{
${ }^{5}$ (Decreto Ley $\left.N^{\circ} 222,1983,2017\right)$ Por el cual se expiden normas sobre contratos de la Nación y sus entidades descentralizadas y se dictan otras disposiciones. Artículo 16. De la Clasificación y de la naturaleza de los contratos- Derogado por el artículo 81 de la Ley N $80,1993$.
} 
administración tiene la capacidad de realizar. Esta disposición legal hizo una clasificación de acuerdo con la naturaleza de los contratos y la tipología contractual en 10 numerales (Santos, $2008)^{6}$, del mismo modo estableció, en el citado artículo 16 del Decreto Ley $\mathrm{N}^{\circ} 222,1983^{7}$, qué contratos correspondían a la administración con régimen de derecho privado ${ }^{8}$.

De lo anterior, se podría inferir que el legislador colombiano dió en ese momento instrumentos que permitían segmentar los contratos celebrados con la administración, incluyendo los interadministrativos que podrían ser utilizados por las diferentes entidades del Estado, pero no había una diferenciación clara entre convenio y contrato interadministrativo, como más adelante se refiere ${ }^{9}$.

En la Ley $N^{\circ}$ 80, 1993, denominado Estatuto General de Contratación Estatal, no se determinó una definición concreta y diferenciadora entre convenio y contrato, sin embargo hasta esa fecha, la regulación en cuanto a los convenios se podía ubicar en determinadas normas de carácter especial, de ahí que la regulación se encontrara en la Ley $\mathrm{N}^{\circ} 29,1990$, en los Decretos Ley $\mathrm{N}^{\circ} 393,1991$ y N 591, 1991.

La Ley $\mathrm{N}^{\circ} 29,1990^{10}$, hace una distinción entre contrato y convenio con la finalidad de

\footnotetext{
${ }^{6}$ La clasificación se dio en lo siguiente: Los de concesión de servicios públicos, obras públicas, prestación de servicios, suministros. Ahora bien, los llamados propiamente "interadministrativos internos que tengan esos mismos objetos", explotación de bienes del Estado, empréstitos, crédito celebrados por la Compañía de Fomento Cinematográfico - FOCINE—, conducción de correos y asociación para la prestación del servicio de correo, y los celebrados por instituciones financieras internacionales públicas, entidades gubernamentales de crédito extranjeras y organismos internacionales con entidades colombianas, cuando no se les considerara como tratados o convenios internacionales. Santos, 2012 p.12).

7 (Decreto Ley N $\left.\mathrm{N}^{\circ 22}, 1983,2017\right)$ Por el cual se expiden normas sobre contratos de la Nación y sus entidades descentralizadas y se dictan otras disposiciones.

8 “...Son contratos de derecho privado de la administración los demás, a menos que ley especial disponga en sentido contrario, y en sus efectos estarán sujetos a las normas civiles, comerciales y laborales, según la naturaleza de los mismos, salvo en lo concerniente a la caducidad...”.

${ }_{9}^{9}$ Inicialmente los contratos interadministrativos se circunscribían a una categoría interna: que tuvieran en su objeto la condición de ser de concesión de servicios públicos, obras públicas, prestación de servicios y suministros. Por otro lado, no se consideraban contratos administrativos, así fueran celebrados entre entidades públicas, aquellos relacionados con los objetos establecidos en los otros cinco puntos de la lista adicional prevista por el mismo artículo 16, del decreto citado. Estos últimos se regían por el derecho privado, los cuales estaría sujetos a las normas civiles, comerciales y laborales, según la naturaleza de los mismos, así como a la jurisdicción ordinaria.

${ }^{10}$ (Ley N ${ }^{\circ} 29,1990$ Febrero 27) Por la cual se dictan disposiciones para el fomento de la investigación científica y el desarrollo tecnológico y se otorgan facultades extraordinarias.
} 
impulsar las actividades de ciencia y tecnología en Colombia ${ }^{11}$, donde otorgó facultades extraordinarias a través de la expedición del Decreto Ley $N^{\circ} 393$, del 8 de febrero de $1991^{12}$ y el Decreto Ley 591 del 26 de febrero de $1991 .^{13}$

De acuerdo con lo expuesto, el legislador colombiano fue desarrollando, a través de los decretos, mecanismos de asociación y de cooperación entre entidades del Estado, y entre entidades y particulares, donde también otorgó la posibilidad de crear sociedades que permitieran cumplir con los fines del Estado ${ }^{14}$.

Por otro lado, frente a los Convenios Interadministrativos, hasta antes de la expedición de la Ley $\mathrm{N}^{\circ}$ 1150, 2007, Ibáñez (2007, p.207) advierte que se debían tener en cuenta tres elementos en primer lugar ser celebrado por la Administración Pública; es decir por una Administración Nacional y/o Territorial y frente a otra con las mismas calidades; dicha definición de administraciones se compone de un conjunto de personas jurídicas previstas en las Constitución y en la ley, en segundo lugar, ser acuerdo que parte de intereses comunes entre la Administración Pública y la persona con quien se celebre el acuerdo, por lo que no se parte de una contraposición de intereses y, en tercer lugar, ser un acuerdo que crea obligaciones entre las partes, esto es vínculos jurídicos en virtud de los cuales las partes se comprometen a realizar prestaciones. No obstante, dichas prestaciones no están encaminadas a lograr la satisfacción de

\footnotetext{
${ }^{11}$ Más que un convenio en ciencia y tecnología lo que se desarrolla es la actividad subvencional del Estado en asocio entre dos entidades públicas y entre entidades públicas y particulares por mandato de la constitución política: Artículo 71 . La búsqueda del conocimiento y la expresión artística son libres. Los planes de desarrollo económico y social incluirán el fomento a las ciencias y, en general, a la cultura. El Estado creará incentivos para personas e instituciones que desarrollen y fomenten la ciencia y la tecnología y las demás manifestaciones culturales, y ofrecerá estímulos especiales a personas e instituciones que ejerzan estas actividades.

${ }^{12}$ Decreto Ley $\mathrm{N}^{\circ} 393,8$ de febrero de 1991, por el cual se dictan normas sobre asociación para actividades científicas y tecnológicas, proyectos de investigación y creación de tecnologías. Se refiere a la reglamentación de mecanismos de asociación con los particulares, por otra parte, el numeral 4 prevé la posibilidad de regular las modalidades de contratos para desarrollar actividades de ciencia y tecnología.

${ }^{13}$ Decreto Ley $\mathrm{N}^{\circ}$ 591, 26 de febrero de 1991, por el cual se regulan las modalidades específicas de contratos de fomento de actividades científicas y tecnológicas. Se vuelve a reglar la posibilidad de celebrar los convenios especiales de cooperación que habían sido reglados en el Decreto Ley $\mathrm{N}^{\circ} 393,1991$ y adicionalmente se reglamentan más mecanismos de asociación para las entidades estatales.

${ }^{14}$ La Ley No 80, 1993, deroga algunas disposiciones del Decreto Ley No 591, 1991. Sin embargo, frente el Decreto Ley N 393, 1991 no se deroga absolutamente nada. Lo anterior ha sido reafirmado por la Corte Constitucional. Dicho Tribunal, al estudiar la constitucionalidad de algunas disposiciones del Decreto Ley $\mathrm{N}^{\circ} 393,1991$ manifestó lo siguiente:
}

(...) el decreto 393 no constituye propiamente un estatuto de contratación. Simplemente prevé entre los mecanismos de asociación para el fomento de la investigación uno especial consistente en la celebración de convenios de cooperación; de ahí la razón por la cual la Ley $\mathrm{N}^{\circ} 80$, 1993 no se ocupó de derogar tal reglamentación (Corte Constitucional, expediente 316, 1995). 
un interés de la contraparte sino a la realización del interés común de ambas partes. Así entonces, se está en presencia de un verdadero negocio jurídico ${ }^{15}$, sólo que el convenio no sería un negocio de contra prestación, sino de colaboración (Ibáñez, 2007, p.207).

\subsection{Concepto y Diferencias entre el Convenio y Contrato Interadministrativo}

En Colombia no hay una posición pacífica acerca de los conceptos de contrato estatal y convenio de la Administración, ni sobre su régimen aplicable. Frente a esta situación vale la pena hacer un análisis sobre lo que ha dicho la jurisprudencia colombiana, la doctrina con posturas similares y disímiles del régimen jurídico y los conceptos de convenio y contrato interadministrativo.

Lo primero que hay que decir es que el convenio interadministrativo podría considerarse como un negocio jurídico de colaboración diferenciándose del contrato estatal, al perseguir intereses y coincidencias entre las partes del convenio, además permite aunar esfuerzos en la búsqueda de un objetivo común. No obstante lo anterior, en la celebración de ese negocio jurídico se generan obligaciones entre los sujetos intervinientes en el convenio que no se pueden traducir solamente en manifestaciones de buena voluntad (Perdomo y Malagón, 2014).

Frente a lo que advierte el autor, de no entender el convenio entre los intervinientes sólo como una relación de buena voluntad, se entiende que la intención de asociarse persigue satisfacer un interés común, de ahí que resulte fundamental previamente identificar la necesidad y la conveniencia que justifica la relación jurídica entre las partes, que posteriormente dan origen

\footnotetext{
${ }^{15}$ En el Artículo 1494 del Código Civil Colombiano Fuente de las obligaciones. Las obligaciones nacen, ya del concurso real de las voluntades de dos o más personas, como en los contratos o convenciones; ya de un hecho voluntario de la persona que se obliga, como en la aceptación de una herencia o legado y en todos los cuasicontratos; ya a consecuencia de un hecho que ha inferido injuria o daño a otra persona, como en los delitos; ya por disposición de la ley, como entre los padres y los hijos de familia.
} 
a unas obligaciones que garanticen el cumplimiento de los objetivos del convenio y el del interés público en común que los llevó a asociarse.

La jurisprudencia ha mantenido unificada la postura en cuanto a los conceptos de contrato y convenio ${ }^{16}$, además ha sido reiterada en las decisiones de la jurisdicción contenciosa ${ }^{17}$ y constitucional $^{18}$, de ahí que en la sentencia de tutela, ya referida, de la Corte Constitucional, se destaque la coincidencia conceptual con el Consejo de Estado ${ }^{19}$ del instrumento jurídico citado, lo que permite inferir que hay una unidad de criterio entre las altas cortes frente a esta definición, donde se resalta que dentro del ánimo de las partes debe primar el interés público, para (Serna y Toller 2000, p.82) el interés público se toma como un conjunto de condiciones que permiten que todas y cada una de las personas y los grupos sociales puedan desenvolverse y alcanzar su plena realización.

Con relación a las posiciones doctrinales se evidencia que conceptualmente existen diferencias entre convenios y contratos, sin embargo asegura que la regulación es idéntica en materia de contratos interadministrativos y convenios interadministrativos ${ }^{20}$.

\footnotetext{
${ }^{16}$ Según (Gaston, 1949) "Si los tribunales administrativos son competentes para los contratos administrativos, es porque se trata de aplicar un régimen especial; el carácter esencial de los contratos administrativos es que se sometan a un conjunto de reglas especiales".

${ }^{17}$ En ese sentido, (Consejo de Estado, 2010). Expediente: 26101. ha considerado lo siguiente:

(...) La Sala considera oportuno aprovechar esta oportunidad para afirmar que los "convenios interadministrativos" cuando quiera que, como en el asunto sub judice, involucran prestaciones patrimoniales, asumen idéntica naturaleza obligatoria y, en consecuencia, idénticos efectos vinculantes y judicialmente exigibles en relación con los que se predican de cualquier otro "acuerdo de dos o más partes para constituir, regular o extinguir entre ellas una relación patrimonial", en los términos del artículo 864 del Código de Comercio.

(...)

los convenios o contratos interadministrativos tienen como características principales las siguientes: (i) constituyen verdaderos contratos en los términos del Código de Comercio cuando su objeto lo constituyen obligaciones patrimoniales; (...) (vi) dan lugar a la creación de obligaciones jurídicamente exigibles; (vii) persiguen una finalidad común a través de la realización de intereses compartidos entre las entidades vinculadas; (...).

${ }^{18}$ Según la (Corte Constitucional, expediente 44214, 2014), los convenios interadministrativos se constituyen como un consenso de voluntades entre entidades públicas y es generador de obligaciones entre las partes que lo suscriben. Su naturaleza jurídica ha sido definida por la jurisprudencia del Consejo de Estado como "expresión de la voluntad colegiada" y es asimilado a un contrato administrativo. Los convenios interadministrativos hacen parte de la actividad contractual del Estado, mediante la cual se obligan, de manera subjetiva, las entidades que lo suscriben, con fines comunes y de interés público.

${ }^{19} \mathrm{El}$ (Consejo de Estado, expediente: 29906, 2014) también ha manifestado que se deben tener en cuenta los principios rectores de la contratación estatal, que aplican a los convenios interadministrativos, entre otros la celebración de estos debe respetar el procedimiento de selección objetiva, específicamente la contratación directa. Así mismo destaca que desconocer dicho procedimiento viola los principios de transparencia, igualdad, libre concurrencia y planeación y, además, genera la nulidad absoluta del contrato por objeto ilícito, al contradecir el derecho público.

${ }^{20}$ Dentro de la causal de contratación directa prevista en la letra d) del numeral 4 del artículo 2 de la Ley $\mathrm{N}^{\circ} 1150,2007$ se encuentran los convenios y los contratos interestatales.
} 
Algunos doctrinantes consideran que los contratos y los convenios interadministrativos son conceptos iguales, está dividida en dos posiciones: un sector iguala los conceptos sin hacer explícitas las razones para llegar a esa conclusión (Suárez, 2009; Palacio, 2010). Otro sector troca los conceptos de contrato interestatal y de convenio interadministrativo, sin ahondar en las razones de ello. Así, en algunas ocasiones se utiliza el segundo cuando en realidad están analizando la normativa que rige el primero (Reyes, 2007); en otros casos se considera que el contrato interestatal tiene como supuesto una igualdad de intereses entre las entidades estatales (Mutis, 2001).

Para (Herrera, 2003) existen diferencias entre el convenio interadministrativo y el contrato interadministrativo. Frente al primero advierte que se constituye una relación de cooperación, aun para prestar servicios propios del Estado, el particular o la entidad pública ejecuta algo para otro ente público. Frente a los contratos interadministrativos, advierte que se celebra entre las dos partes-entidades públicas- un verdadero negocio. Es decir, el contrato persigue un lucro como contraprestación mientras que en el convenio se busca poner entre las partes una serie de intereses que persiguen solamente satisfacer la entrega de bienes y servicios. Advierte incluso que una gran diferencia entre los dos radica en que en el convenio no hay una relación de coordinación sino de sujeción.

De lo expuesto por (Herrera, 2003), otra diferencia entre contrato y convenio es que en el convenio el beneficiario de su acuerdo es un tercero, que siempre debe ser la comunidad, mientras que en el contrato una de las partes busca un beneficio, aun en los casos cuando se trate de un contrato interadministrativo. Sin embargo, una característica que resalta es que existe una sujeción entre las partes del convenio, lo podría llegar a hacer dispar de lo que se ha venido sosteniendo, en la medida en que el acuerdo de voluntades para aunar esfuerzos no se podría 
interpretar como una posición dominante de una de las partes sobre otra, sino al contrario, se diría que las partes están en posiciones de igualdad. No habría conmutatividad en el acuerdo o documentos suscritos entre ellos, se determinarían unas tareas u obligaciones específicas por cumplir, sin perjuicio, sin que deban cumplir con los compromisos fijados y sin que se configure un escenario de subordinación en el marco del convenio.

Para explicar brevemente qué se entiende por la teoría de la sujeción según (López, 1994), se puede entender como las relaciones jurídico-administrativas caracterizadas por una duradera y efectiva inserción del administrado en la esfera organizativa de la administración, a resultas de la cual queda sometido a un régimen jurídico peculiar que se traduce en un tratamiento especial de la libertad y de los derechos fundamentales, así como de sus instituciones como garantía, además dá forma a los fines típicos de cada relación, es decir, estas relaciones jurídicas que tienen como una de las partes a la administración pública, afirman poderes y deberes para ambas partes, sin embargo, esta atribución no oscurece el hecho de que una de las partes guarda cierta supremacía una sobre la otra, que inclina, por así decirlo la balanza de poderes hacia su favor.

La Ley $\mathrm{N}^{\circ} 1474,2011^{21}$ en sus artículos 92 y 95, hace referencia a los contratos interadministrativos y deja de lado a los convenios. Claramente advierte que existe entre las partes del contrato un ánimo de obligarse entre sí y de tener contraprestaciones distintas en las que se pueden enmarcar los contratos de prestación de servicios y de suministro entre otros, siempre y cuando entre su actividad misional quien preste el servicio esté facultado para hacerlo.

En conclusión, después de citar varias posturas doctrinales y jurisprudenciales sobre el contrato y convenio interadministrativo, diferencias, similitudes, evolución normativa en la

\footnotetext{
${ }^{21}$ Ley $\mathrm{N}^{\circ}$ 1474, 2011.Por la cual se dictan normas orientadas a fortalecer los mecanismos de prevención, investigación y sanción de actos de corrupción y la efectividad del control de la gestión pública.
} 
legislación colombiana, se puede inferir que las posturas no son del todo pacíficas y la discusión sí permite sacar rasgos y características de cada figura que hace más fácil la utilización de estas herramientas a los operadores de la administración.

\subsection{Contrato interadministrativo como instrumento jurídico de la Administración}

\section{Pública en Ecuador}

Los contratos públicos administrativos o contratos públicos, según la doctrina ecuatoriana se definen como una declaración voluntaria común, un acto bilateral propio de la manifestación de la voluntad consciente entre las partes, que produce efectos jurídicos entre un ente estatal, en ejercicio de la función administrativa, y un ente particular, sea este una persona natural o jurídica pública o privada (Aguirre, 2016).

El marco regulatorio vigente de la contratación estatal en la república ecuatoriana se encuentra en la Ley Orgánica del Sistema Nacional de Contratación Pública (LOSNCP). A partir de su promulgación, que data desde el año 2008, se han presentado modificaciones en los años 2009, 2013, 2014 y $2015^{22}$. Este nuevo estatuto de la contratación ecuatoriana, que en efecto es bastante reciente en comparación con el reglado en la legislación colombiana, introdujo una serie de modificaciones con el objetivo de tener un estatuto a la vanguardia de las necesidades del Estado, que tiene como objetivo que el sector público sea más efíciente y dinámico, en los procesos de selección, y transparente frente a la lucha contra la corrupción.

\footnotetext{
${ }^{22}$ En el R.O.S. 48 de 16 de octubre de 2009 se expidió la Ley Orgánica de Empresas Públicas (LOEP) en la que se introdujo una reforma al artículo 2 número 8 de la LOSNCP que es objeto de análisis en el presente artículo. En el R.O.S. 5 de 31 de mayo de 2013 se trasladaron al SERCOP (máximo organismo de Contratación Pública del Ecuador) algunas facultades que estuvieron a cargo del Ministerio de Industrias y Productividad. En el R.O.S. 100 de 14 de Octubre de 2013 se introdujeron varias reformas orientadas a fortalecer la producción nacional y el valor agregado ecuatoriano y también se introdujo una reforma al artículo 2 número 8 de la LOSNCP. En el R.O.S. 332 de 12 de septiembre de 2014, al expedirse el Código Orgánico Monetario y Financiero se agregó un procedimiento de contratación de régimen especial para la adquisición de oro por parte del Banco Central del Ecuador, que implicó modificar (incluyendo un numeral) el artículo 2 de la LOSNCP. Y finalmente, en el R.O.S. 652 de 18 de diciembre de 2015, con ocasión de la expedición de la Ley Orgánica de Incentivos para Asociaciones Público Privadas y la Inversión Extranjera, también se introduce una nueva reforma al artículo 2 número 8.
} 
Para el tema presente se puede decir que en la legislación ecuatoriana, los contratos interadministrativos se utilizan como una medida excepcional ${ }^{23}$, con la finalidad que entre entidades públicas se puedan proveer bienes y servicios entre sí, siempre y cuando exista la conveniencia y la necesidad de conformidad con el estatuto de contratación actual. Para ello, dentro del ordenamiento jurídico ecuatoriano, se ha estructurado un procedimiento especial que se expondrá, después de aclarar que la principal función que el Estado tiene frente a los ciudadanos es satisfacer el interés general y el bien común, por consiguiente, para cumplir con estas responsabilidades debe contratar y proveer bienes y servicios con particulares o terceros que tengan la capacidad para hacerlo, como también estaría facultado para contratar con entidades del sector público, siempre y cuando cumplan con las disposiciones legales establecidas en la ley (Tapia Rosales, 2013), hecho que se asemeja a lo que también se utiliza en el Estado colombiano.

La ley orgánica de contratación pública del Ecuador, en el numeral 2.8 del artículo 2 consagró la reglamentación de la contratación interadministrativa, sin embargo, (Baldeón, 2008) señala algunas características del citado contrato en lo siguiente: 1. El objeto contractual es uno de los previstos en dicho cuerpo normativo (ejecución de obras, prestación de servicios incluidos los de consultoría o provisión de bienes). 2 . Son contratos de naturaleza bilateral y onerosa; pues generan obligaciones recíprocas para las partes con la correspondiente contraprestación económica. 3. Tienen el carácter interadministrativo en el sentido de entender que el ente contratante es público o privado con capital o recursos públicos mayoritarios; y, que el contratista es también público o privado con capital o recursos públicos mayoritarios. 4. El concepto de lo público, trasciende la frontera nacional, pues se consideran como contratistas

\footnotetext{
${ }^{23}$ Frente a la utilización de esta figura de los contratos interadministrativo en el estado colombiano se puede afirmar que también tiene el carácter excepcional al igual que en la legislación ecuatoriana. Desde la Ley $\mathrm{N}^{\circ} 1150,2017$ se consagró como regla excepcional la contratación directa, figura condicionada para determinadas circunstancias previstas en la ley.
} 
públicos no solo a las empresas públicas ecuatorianas sino también a aquellas de naturaleza pública que pertenezcan a la comunidad internacional, contratistas que sean empresas públicas nacionales e internacionales en las cuales haya recurso público mayoritario (Baldeón Barriga, 2014) 5. Son procesos generalmente de contratación directa, sin importar el monto del presupuesto referencial en juego. 6. Se deben cumplir los requisitos previstos para todo proceso de contratación, en observancia del carácter de régimen especial que éste tiene.

Así mismo, en la regulación normativa descrita en el artículo 2 de la Ley Orgánica del Sistema Nacional de Contratación Pública (LOSNCP), le da una facultad al presidente de la república de reglamentar los procedimientos precontractuales en los contratos interadministrativos (Baldeón, 2016), bajo criterios de selectividad. No obstante, en principio se presenta una preocupación de conformidad con lo que advierte (Tapia, 2013) al indicar la ausencia de reglamentación del criterio de selectividad en los contratos interadministrativos (contratos entre entidades públicas), ya que ha venido ocasionando la vulneración de los principios de derecho administrativo más importantes como son el de legalidad y discrecionalidad. Puesto que el criterio de selectividad no se encuentra desarrollado ni estructurado en la ley ni en el reglamento general, así como tampoco el $\mathrm{INCOP}^{24}$. Por lo anterior, se puede concluir que si bien se presentan características similares entre los contratos interadministrativos regulados tanto en Colombia como en Ecuador también se puede evidenciar algunas diferencias, como por ejemplo que en el ordenamiento jurídico ecuatoriano se prevé un proceso pre contractual especial para llegar a la adjudicación del contrato a una entidad pública. Así mismo, la normativa vigente ecuatoriana establece como una excepción a este tipo de contrataciones la obligación de presentar garantías tanto de fiel cumplimiento como de buen uso

\footnotetext{
${ }^{24}$ El INCOP - Instituto Nacional de Contratación Pública es el organismo de derecho público que ejerce la rectoría del sistema nacional de contratación pública; creado en el año 2008 dentro del gobierno del ex presidente Eco. Rafael Correa.
} 
del anticipo, que son condiciones obligatorias para los contratistas particulares, incluso para las contrataciones entre entidades del sector público conforme la normativa vigente ecuatoriana se deben regir a un procedimiento especial que se realizará a través de contratación directa, pudiéndose contratar también a través de este procedimiento a entidades públicas de la comunidad internacional, siempre y cuando en los tratados o convenios firmados con los países de estas entidades no se haya establecido un procedimiento diferente, aquí se abre pues la posibilidad de que el Estado pueda cumplir con sus objetivos con el concurso de entidades públicas internacionales (Moreno, 2011).

\subsection{De las cláusulas excepcionales fijadas en los contratos estatales en Colombia.}

Al hablar de "disposiciones extrañas a la contratación particular", se hace referencia específicamente a las llamadas cláusulas exorbitantes o excepcionales al derecho común, a través de las cuales a la entidad pública contratante se le reconoce una serie de prerrogativas que no ostentan los particulares, y que tienen como fundamento la prevalencia no sólo del interés general sino de los fines estatales (Tafur, 2001). Partiendo de la base que dichas prerrogativas que se otorgan a las entidades públicas en el marco de un contrato estatal proviene del legislador y no del acuerdo de voluntades o de la decisión unilateral de la administración. Por lo tanto el mandato legal hace obligatoria la inclusión, perdiendo así la disponibilidad de las partes sobre la misma (Güecha Medina, 2006).

Para (Dávila, 2016) estas cláusulas regladas por el legislador colombiano, son verdaderas potestades o poderes que la ley le confiere a la parte pública del contrato que en materia de contratación estatal, no se inspiran en el acuerdo voluntario ni pueden nacer en virtud de él por clara violación del principio de legalidad, sino que emergen de mandato expreso, la imposibilidad de renunciar a las cláusulas exorbitantes, instrumentadas como prerrogativas y/o 
privilegio de la administración sobre sus contratistas, se da en todas las etapas de la contratación (Niño, 2011).

Estos intereses y fines permiten a la administración hacer uso de ciertos poderes del Estado, como lo expone el tratadista (Garrido, 2010), el carácter excepcional de los cuales recurre a la administración, a efectos de declarar la caducidad del contrato, su terminación, su modificación e interpretación unilateral, como medidas extremas que debe adoptar después de agotar otros mecanismos para la debida ejecución del contrato, cuya finalidad es evitar la paralización de éste y hacer viable la continua y adecuada prestación del servicio que estos pueden comportar, en atención al interés público implícito en ellos.

A su turno (Marienhoff M. S., 1970), denomina las cláusulas exorbitantes del derecho común como aquellas que sobrepasan el ámbito de ese derecho, sea porque en este dichas cláusulas son "inusuales" o porque, incluidas en un contrato de derecho privado, resultarían “ilícitas” por exceder el ámbito de la libertad contractual. En tales supuestos el contrato será “administrativo" por el solo hecho de contener dichas "cláusulas exorbitantes”.

Una diferenciación entre los contratos de derecho privado y contratos de derecho público, se identifica en la utilización de estas cláusulas atípicas. Es decir, un contrato que estipule cláusulas extrañas o inhabituales o de prerrogativas de poder público, el contrato es de naturaleza pública (Foillard, 2004). De ahí que la administración tiene la posibilidad mediante actos administrativos, de tomar decisiones en ejercicio de las prerrogativas o cláusulas exorbitantes sin necesidad de acudir al juez (Jiménez Blanco, 2002).

Sobre el ejercicio de estos poderes el (Consejo de Estado, expediente: 15802 2002) ha señalado que son actos unilaterales de indiscutible factura y sólo pueden ser dictados por la administración en ejercicio de poderes legales, denominados generalmente exorbitantes. El 
hecho que tales actos se dicten en desarrollo de un contrato, no les da una fisonomía propia, porque el contrato no es la fuente que dimana el poder para expedirlos, sino está únicamente en la ley. Esos poderes, así, no los otorga el contrato y su ejercicio no puede ser objeto de convenio.

El artículo 14 de la Ley $N^{\circ} 80,1993$, emplea los términos de potestades excepcionales o de cláusulas excepcionales, también conocidas como cláusulas exorbitantes. Para (Expósito, 2013) define las cláusulas excepcionales como: "un mecanismo encaminado a preservar la legalidad de los actos de las autoridades públicas, comprendido por el conjunto de prerrogativas que ostenta la administración en el ámbito contractual dirigido tutelas el interés público de la comunidad". Estas potestades pueden ser ejercidas por la administración como manifestación de su imperium o poder de estado, que se concreta en el poder jurídico para imponer coactivamente su voluntad, lo cual debe matizarse, dado que estas prerrogativas solo podrán ser ejercidas en las situaciones de hecho previamente establecidas por la ley y dentro de los límites señalados por la misma.

Como se puede inferir a partir de lo expresado por la ley y la doctrina, estas cláusulas se configuran como prerrogativas que afectan la igualdad entre el Estado y los particulares, confiriendo facultades que solo podrían utilizar las entidades estatales ante eventuales hechos. Tales potestades excepcionales se justifican dentro del ordenamiento jurídico colombiano con la finalidad de proteger el interés público general.

El (Consejo de Estado, expediente: 16075, 2008) define este tipo de prerrogativas como: "Los poderes exorbitantes son facultades regladas que emanan del poder público y se originan en la ley, con fundamento en las cuales la administración puede dirigir, controlar, interpretar, modificar, terminar, sancionar y caducar, en forma unilateral, el contrato, los cuales deben ejercerse mediante actos administrativos motivados, de conformidad con un procedimiento 
establecido y dentro de ciertos límites fijados por el orden jurídico.

En conclusión se puede inferir que en los contratos estatales se estipulan dos tipologías de cláusulas cuyas características, por un lado son las que nacen del acuerdo de voluntades, es decir del postulado de autonomía de la voluntad, donde está la administración versus cocontratante, (Sayaguez Laso, 1998) y como resultado se da el pacto y, por otro lado, las cláusulas que dan prerrogativas a la administración como medios de dirección y control dentro del contrato, las denominadas cláusulas exorbitantes (Correa, 2008).

Sobre estas últimas cabe hacer una claridad en la medida en que las cláusulas exorbitantes no se pueden considerar como un poder abusivo o desbordado que tiene la administración frente al más débil en los contratos estatales. Se debe tener en cuenta que estos poderes especiales que la ley colombiana le da al Estado se dan con la finalidad de proteger el interés público, ya que pueden presentarse situaciones en las que se vea alterada la debida ejecución de los contratos o la prestación del servicio (Solano Sierra, 1994). En estas situaciones el Estado, por medio de sus entidades, debe actuar oportunamente en el uso de los citados poderes como garante de sus propios intereses ${ }^{25}$. Más aun como lo advierte (Pérez Hualde, 2011) el legislador estimó que excepcionalmente la administración aplique unas modulaciones a las instituciones contractuales del derecho privado con la finalidad de garantizar la prestación eficiente del servicio público que se busca satisfacer con el contrato. Tales modulaciones no se aplican dentro del marco de igualdad entre las partes que implica la institución contractual en el

\footnotetext{
${ }^{25}$ Artículo 3 de la Ley $\mathrm{N}^{\circ}$ 80, 1993, Los servidores públicos tendrán en consideración que al celebrar contratos y con la ejecución de los mismos, las entidades buscan el cumplimiento de los fines estatales, la continua y eficiente prestación de los servicios públicos y la efectividad de los derechos e intereses de los administrados que colaboran con ellas en la consecución de dichos fines.

Los particulares, por su parte, tendrán en cuenta al celebrar y ejecutar contratos con las entidades estatales que, además de la obtención de utilidades cuya protección garantiza el Estado, colaboran con ellas en el logro de sus fines y cumplen una función social que, como tal, implica obligaciones.
} 
derecho privado. Por el contrario, aquellas modulaciones tienen relación con la investidura de "poder" de la que goza el Estado en la mayoría de sus manifestaciones que producen efectos jurídicos.

Ya en el caso concreto del problema jurídico que se formuló para el trabajo de investigación, al cual más adelante se hará referencia en detalle, se advierte que la doctrina que se encontró en el desarrollo del trabajo se circunscribe a que las cláusulas exorbitantes son las taxativamente señaladas en la ley, lo que permite inferir que frente a los poderes exorbitantes que puede usar la administración pública, en el marco de un contrato estatal, se regula con lo establecido por la Ley No 80, 1993 en los artículos 14 a 19.

\subsection{Clasificación de las cláusulas excepcionales en Colombia}

Después de enunciar y explicar que el objetivo de la administración pública al utilizar cláusulas exorbitantes, en los contratos del Estado, es el de garantizar la salvaguarda del interés general, es pertinente desarrollar cada una de estas potestades con la finalidad de exponer su utilidad, la pertinencia y la función de cada cláusula frente a los inconvenientes que se podrían suscitar en la ejecución de los contratos.

Un grupo de cláusulas exorbitantes regladas por el legislador colombiano que vale la pena enunciar, es el de aquellas que hacen referencia a evitar la paralización de la prestación del bien, es decir, aquellas cláusulas en las que la entidad le dé de forma unilateral, por medio de un acto administrativo, una orientación al contrato sin perjuicio de reconocer el restablecimiento del equilibrio económico, por las decisiones tomadas sin consultar a la otra parte. 


\subsubsection{Interpretación Unilateral del Contrato Estatal}

Como primera potestad excepcional se encuentra la interpretación unilateral del contrato $^{26}$, reglada en el artículo 15 de la Ley $\mathrm{N}^{\circ} 80,1993$, frente a esta facultad que se le otorga al Estado de aplicarla en los contratos estatales, obedece a situaciones confusas, ambiguas que den lugar a interpretaciones que no se hayan estipulado en los contratos con la suficiente claridad, al respecto (Dávila 2016, p. 632) advierte que con el fin de evitar la parálisis del contrato y afectar, por ende, los intereses colectivos que con él se pretenden satisfacer, se puede interpretar el contrato cuando existan cláusulas confusas y divergentes o ambiguas que se convierten en la causa de tal parálisis. De manera que se configure esta potestad se requiere la presencia de dos condiciones esenciales: que existan estipulaciones ambiguas, confusas o contradictorias. Que esa situación tenga paralizado el contrato o amenace con paralizarlo por no existir claridad acerca del sentido de un aspecto trascendental para la ejecución del contrato.

Así mismo, el (Consejo de Estado, expediente: 1293, 2000) advierte que la facultad excepcional de la interpretación unilateral sólo puede extenderse a las estipulaciones o cláusulas objeto de la diferencia, razón por la cual la administración tendrá como limitación que no podrá extenderse a materias sobre las cuales no tengan discrepancia las partes.

Estas discrepancias o dudas deben ser despejadas en primer término por las mismas partes y en última instancia será el juez el que las despeje, cuando aquellas no hayan logrado un acuerdo y como consecuencia se haya producido el rompimiento de la relación. Aunque la ley no lo diga expresamente ese poder exorbitante de interpretación, con efectos coercitivos, tiene como

\footnotetext{
${ }^{26}$ Contra los actos administrativos que ordenen la interpretación, modificación y terminación unilaterales, señala la misma norma que "procederá el recurso de reposición, sin perjuicio de la acción contractual que puede intentar el contratista, según lo previsto en el artículo 77 de esta Ley $\mathrm{N}^{\circ} 80,1993$.
} 
límite temporal para su ejercicio la vigencia del contrato. Así, por ejemplo, en el contrato de obra pública en el que conviene un término para la ejecución de la obra, hasta el vencimiento del mismo. El poder de interpretación (Consejo de Estado, expediente: 1293, 2000) no puede confundirse con el de modificación, también contemplado en la ley, porque este tiene unos alcances y efectos diferentes (Dávila, 2016).

Frente a esta primera cláusula de interpretación unilateral del contrato, vista como una facultad y/o atribución que tienen las entidades estatales de responsabilidad para el control y vigilancia en la ejecución del contrato, y que presupone la existencia de límites en la competencia para su expedición, marca una notable diferencia de la modificación unilateral a partir que la interpretación en el contrato parte que el contenido material de la cláusula esta enunciado y lo que se busca es una nueva forma de expresión que consiste en explicar y aclarar el alcance y el límite del contenido en discusión de la cláusula con la finalidad de favorecer el interés público que está siendo amenazado o vulnerado en el marco del contrato estatal.

\subsubsection{Modificación Unilateral del Contrato Estatal}

Por regla general, los contratos estatales pueden ser modificados en su clausulado cuando sea necesario, con el propósito de lograr su finalidad que persigue la realización de los fines del Estado, a los cuales sirve el contrato. Según (Marienhoff 1966, p.397) en esta potestad la parálisis del contrato y la afectación del servicio se evitan modificando el contrato en razón a que la administración no puede quedar indefinidamente ligada por contratos que se han convertido en inútiles, o por estipulaciones contractuales que actualmente resultan inadecuadas para satisfacer las necesidades originariamente tenidas en cuenta. Así lo estipulan los artículos 14 y 16 de la Ley $\mathrm{N}^{\circ} 80,1993$, los cuales facultan a la entidades contratantes a modificar los 
contratos de común acuerdo o de forma unilateral, sin perjuicio que se haya previamente agotado el procedimiento del primero, es decir que se haya surtido en principio la modificación de común acuerdo, sin embargo, frente al poder de la unilateralidad de la que está revestido, las entidades públicas hay que advertir que se puede surtir en la medida que se busque evitar la paralización o la afectación grave de los servicios públicos a su cargo y asegurar la inmediata, continua y adecuada prestación del mismo (Dávila, 2016).

Este poder de modificación unilateral es también conocido por la doctrina como lus variandi, dicho poder, como todos los que se le confieren a la administración, debe ejercerse dentro de unos límites, los cuales buscan evitar una aplicación desbordada que genere perjuicios para el contratista. Para ponerle límite a esta herramienta jurídica existe el fundamento normativo de esta segunda potestad excepcional, descrito en el artículo 16 de la Ley $\mathrm{N}^{\circ} 80,1993$ que advierte lo siguiente: "Modificación Unilateral. Si durante la ejecución del contrato y para evitar la paralización o la afectación grave del servicio que se deba satisfacer con él, fuere necesario introducir variaciones en el contrato y previamente las partes no llegan al acuerdo respectivo, la entidad en acto administrativo debidamente motivado, lo modificará mediante la supresión o adición de obras, trabajos, suministros o servicios".

Esto quiere decir, que la misma norma prevé una serie de condicionamientos en la que delimita las situaciones en las que las entidades públicas pueden hacer uso de esta facultad, evitando de esta forma que caprichosamente las administraciones introduzcan modificaciones sin estar sujetos a controles.

La administración podrá modificar unilateralmente un contrato, siempre y cuando se cumplan los requisitos que impone el artículo 16 de la Ley $\mathrm{N}^{\circ}$ 80, 1993: Falta de acuerdo entre 
las partes: es decir, ausencia de consentimiento acerca de la naturaleza y/o el contenido de las modificaciones; existencia de la necesidad de introducir variaciones en el contrato para impedir la paralización del servicio o la afectación grave del servicio público que se deba satisfacer con él; que la discrepancia referida se manifieste durante la etapa de ejecución del contrato. Se debe tener en cuenta que, en los casos en que la entidad contratante imponga modificaciones que alteren más del 20\% del valor del contrato, surge para el contratista el derecho de renunciar a la ejecución del mismo, razón por la cual, la entidad ordenará su liquidación no sin antes tomar todas las medidas pertinentes para garantizar la terminación del objeto contractual.

Según lo descrito anteriormente, podrían presentarse situaciones en algunas cláusulas redactadas en el contrato estatal, inútiles o inadecuadas por circunstancias no previsibles, que obligarían a la administración a modificarlas en cuanto a que podrían desfavorecer el interés público y el cumplimiento material del objeto de la contratación con la que se pretende satisfacer el interés general ${ }^{27}$.

(García y Fernández, 2000) señala: No se trata, (...) de límites en el sentido de barreras u obstáculos que impidan a la administración pública modificar en ciertos casos los contratos administrativos por ella suscritos (..) Límites en este sentido no existen ni pueden existir, porque las exigencias del interés público, el servicio a la comunidad, no pueden quedar comprometidos por el error inicial de la administración contratante o por un cambio en las circunstancia (sic)

\footnotetext{
${ }^{27}$ (García y Fernández 2000, p.724) señalan: "No se trata, (...) de límites en el sentido de barreras u obstáculos que impidan a la administración Pública modificar en ciertos casos los contratos administrativos por ella suscritos (..) Límites en este sentido no existen ni pueden existir, porque las exigencias del interés público, el servicio a la comunidad, no pueden quedar comprometidos por el error inicial de la administración contratante o por un cambio en las circunstancia (sic) originalmente tenidas en cuenta en el momento de contratar. El interés general debe prevalecer en todo caso y en cualquiera de las circunstancias, porque, de otro modo, sería la propia comunidad la que habría de padecer las consecuencias. Obligar a la comunidad a soportar una carretera, un puerto o un embalse mal planteado ab initio, inútiles o ineficaces desde su misma concepción, por un simple respeto al contractus lex, no tendría sentido. Al servicio del interés público y de sus concretas e insoslayables exigencias, el lus variandi de la administración contratante es limitado en su extensión o intensidad, ya que el interés público prima sobre cualquier consideración.
} 
originalmente tenidas en cuenta en el momento de contratar. El interés general debe prevalecer en todo caso y en cualquiera de las circunstancias, porque, de otro modo, sería la propia comunidad la que habría de padecer las consecuencias. Obligar a la comunidad a soportar una carretera, un puerto o un embalse mal planteado ab initio, inútiles o ineficaces desde su misma concepción, por un simple respeto al contractus lex, no tendría sentido. Al servicio del interés público y de sus concretas e insoslayables exigencias, el lus variandi de la administración contratante es limitado en su extensión o intensidad, ya que el interés público prima sobre cualquier consideración.

Por otro lado, es preciso advertir que en virtud de esta potestad de modificación unilateral del contratos, cuando la entidad decida reformar las cláusulas del contrato, el objeto del contrato no podría ser susceptible de modificación, pues ello significaría celebrar un contrato diferente que implicaría adelantar el proceso de selección respectivo, es decir que la potestad de modificar unilateralmente el contrato no puede servir de excusa para burlar los procesos de selección objetiva, como quiera que ello no sólo atenta contra los principios de la función pública sino que además podría acarrear sanciones disciplinarias, fiscales, patrimoniales e incluso penales para el servidor público que, valiéndose de este poder exorbitante, intente evitar adelantar el trámite previsto en la Ley $\mathrm{N}^{\circ}$ 80, 1993 para escoger al contratista (Consejo de Estado, expediente: 1453, 2003). Así mismo, (Expósito, 2013) ratifica lo antes ya dicho en los siguientes términos:

"Se trata de una práctica, versátil y coherente con el principio de mutabilidad del contrato administrativo, que permite a la administración pública adaptar el contenido del contrato estatal a las necesidades de servicio público en cuanto a la introducción o transformación de actividades concretas dentro del objeto pactado, sin poder en ningún momento variar el mismo, 
ya que de ser así se estaría ante la celebración de un contrato diferente, que requiere del agotamiento del procedimiento de selección correspondiente."

En conclusión, frente a la modificación unilateral se puede advertir que para los casos en los que no haya consenso directamente entre la entidad estatal y el contratista, la modificación es ejercida por medio de un acto administrativo debidamente motivado, en el cual se hará una exposición de motivos, así mismo teniendo en cuenta el ejemplo que da (Franco, 2000): “(...) se procederá a modificar el contrato suprimiendo obras que se habían contratado antes; adicionando obras que no se habían contemplado en el contrato inicial; estableciendo nuevas cantidades de trabajos a ejecutar; determinando los nuevos suministros a adquirir o suprimiendo los que inicialmente se habían solicitado o determinado o suprimiendo servicios.”

De igual forma, se concluye que en cuanto a la diferencia con el derecho privado el acuerdo con modificación unilateral surgida, bien sea del contrato o de la intención de las partes, como expresión de la autonomía de la voluntad en la contratación estatal, la administración no requiere del consentimiento como claramente lo advierte (Benavides, 2004). En efecto, la teoría del acto administrativo se construye a partir del poder particular de la administración de definir una situación jurídica creadora de derechos y obligaciones para terceros (los administrados) sin obtener previamente su acuerdo. (Benavides, 2004).

Por último se puede concluir, con relación al parágrafo del artículo 16 de la Ley $\mathrm{N}^{\circ} 80$, 1993, cuando advierte la posibilidad del contratista de renunciar a la ejecución del contrato, si las modificaciones alteran el valor del contrato en $20 \%$ o más del valor inicial, que se constituye como un límite adicional a la facultad de modificación unilateral por parte de las entidades estatales. Si se presenta esa circunstancia se procede a la liquidación del contrato, teniendo la 
entidad la obligación de adoptar las medidas necesarias para garantizar la terminación del objeto del mismo.

\subsubsection{Terminación Unilateral del Contrato Estatal}

La tercera prerrogativa de este estudio se circunscribe a la figura de la terminación unilateral que tiene la administración pública sobre los contratos estatales. Esta herramienta jurídica se considera como un evento anormal del contrato, pues la entidad debe garantizar la correcta ejecución del mismo que apunte a garantizar el cumplimiento de los fines del Estado, sin embargo, el legislador colombiano prevé algunas situaciones regladas en el artículo $17^{28}$ de la Ley $\mathrm{N}^{\circ} 80,1993$, mediante los cuales la entidad en acto administrativo debidamente motivado dispondrá la terminación anticipada del contrato estatal.

El (Consejo de Estado, expediente 24510, 2013) se ha pronunciado sobre la terminación unilateral en los contratos estatales ${ }^{29}$, por lo que se encuentra una clara posición sentada por esta

\footnotetext{
${ }^{28}$ Artículo 17. De la Terminación Unilateral. La entidad en acto administrativo debidamente motivado dispondrá la terminación anticipada del contrato en los siguientes eventos: 1o. Cuando las exigencias del servicio público lo requieran o la situación de orden público lo imponga. 20. Por muerte o incapacidad física permanente del contratista, si es persona natural, o por disolución de la persona jurídica del contratista. 30. Por interdicción judicial de declaración de quiebra del contratista. 4o. Por cesación de pagos, concurso de acreedores o embargos judiciales del contratista que afecten de manera grave el cumplimiento del contrato.
}

Sin embargo, en los casos a los que se refieren los numerales 2o. y 3o. de este artículo podrá continuarse la ejecución con el garante de la obligación.

La iniciación de trámite concordatario no dará lugar a la declaratoria de terminación unilateral. En tal evento la ejecución se hará con sujeción a las normas sobre administración de negocios del deudor en concordato. La entidad dispondrá las medidas de inspección, control y vigilancia necesarias para asegurar el cumplimiento del objeto contractual e impedir la paralización del servicio.

29 “Así que las terminaciones unilaterales y discrecionales de los contratos estatales no son admisibles y esta afirmación se corrobora fácilmente con sólo repasar las normas de la contratación estatal, en especial los artículos 17, 18 y 45 de la Ley $\mathrm{N}^{\circ} 80$, 1993, de donde se desprende que la potestad que tiene la administración para dar por terminado unilateralmente el contrato no es discrecional sino que está reglada, como toda actividad administrativa, y que debe ejercerse con fundamento en las expresas y precisas causas, y solo en ellas, que están previstas en la ley (...).

Con otras palabras significa que la potestad exorbitante que tiene la administración de dar por terminado el contrato no es una facultad discrecional sino que debe cimentarse en las causales previstas en la Ley y, por consiguiente, en ningún caso puede soportarse la decisión en una cláusula contractual que no tenga correspondencia con una causa legalmente prevista.

Y como la determinación que haya de tomar la administración debe verterse en un acto administrativo, éste no sólo debe ser comunicado sino que además debe ser debidamente motivado y en su producción ha debido hacerse efectivo el debido proceso permitiendo la audiencia y la defensa del contratista". 
corporación frente a este instrumento que advierte las limitaciones con las que cuenta el operador de la administración, cimentado en las causales que taxativamente se encuentran señaladas en la ley para la utilización de la terminación unilateral en los contratos estatales. También resulta importante advertir que a las entidades públicas "les está vedado incluir otras causales de terminación unilateral en el contrato o los pliegos de condiciones, so pena de nulidad de la respectiva cláusula y de los actos que se fundamenten en ella (Consejo de Estado, expediente 24510, 2013).

De igual forma, resulta conveniente precisar que la terminación unilateral del contrato "no genera inhabilidad y por ende, no afecta la capacidad contractual en futuros procesos de selección, de manera tal que la entidad no puede rechazar una oferta por el hecho de que al proponente se le haya terminado unilateralmente otro contrato, y tampoco puede abstenerse de adjudicarle el contrato por esa misma razón" (Consejo de Estado, expediente 24510, 2013).

En conclusión, se advierte que el espacio temporal para la aplicación de la terminación unilateral de los contratos se circunscribe siempre y cuando a que haya obligaciones pendientes por ejecutar por parte del contratista y se excluye la posibilidad de hacer uso de esta potestad durante la etapa de liquidación (Consejo de Estado, expediente 26.938, 2015). Así mismo como característica final de esta figura jurídica se puede decir que son sobrevinientes, factor que reviste capital importancia en el momento de examinar si la entidad usó correctamente esta prerrogativa. 


\subsubsection{Caducidad del Contrato Estatal}

Otra potestad con la que cuenta la administración para conjurar situaciones anormales en la ejecución de los contratos estatales es la caducidad, según (Beltrán, 1998) la caducidad del contrato es una prerrogativa del Estado, para dar por terminado un contrato donde él estado es parte y el contratista ha desplegado ciertas conductas o se presentan circunstancias que, en general, impiden el cumplimiento eficaz y adecuado del objeto contractual, hecho que hace necesaria la intervención rápida de la administración a fin de garantizar que el interés general involucrado en el contrato mismo no se afecte, porque de hecho se lesiona a la comunidad en general. Es decir, la caducidad del contrato es una potestad que se le reconoce al Estado como parte en él, para darlo por terminado.

Este instrumento reglado por el legislador colombiano en el artículo 18 de la Ley $\mathrm{N}^{\circ} 80$, $1993^{30}$, permite tomar medidas cuando el contratista sin justificación está incumpliendo y se evidencia una parálisis en la prestación de los bienes o servicios a proveer por el contratista, generando un recurrente perjuicio al Estado al incumplirse el objeto y las obligaciones que le

\footnotetext{
${ }^{30} \mathrm{El}$ artículo 18 de la Ley $\mathrm{N}^{\circ} 80,1993$, establece los siguiente frente a la caducidad:

Artículo 18. De la Caducidad y sus Efectos. La caducidad es la estipulación en virtud de la cual si se presenta alguno de los hechos constitutivos de incumplimiento de las obligaciones a cargo del contratista, que afecte de manera grave y directa la ejecución del contrato y evidencia que puede conducir a su paralización, la entidad por medio de acto administrativo debidamente motivado lo dará por terminado y ordenará su liquidación en el estado en que se encuentre.
}

\footnotetext{
En caso de que la entidad decida abstenerse de declarar la caducidad, adoptará las medidas de control e intervención necesarias, que garanticen la ejecución del objeto contratado. La declaratoria de caducidad no impedirá que la entidad contratante tome posesión de la obra o continúe inmediatamente la ejecución del objeto contratado, bien sea a través del garante o de otro contratista, a quien a su vez se le podrá declarar la caducidad, cuando a ello hubiere lugar.
}

Si se declara la caducidad no habrá lugar a indemnización para el contratista, quien se hará acreedor a las sanciones e inhabilidades previstas en esta ley.

La declaratoria de caducidad será constitutiva del siniestro de incumplimiento. 
fueron encomendados al tercero responsable de la ejecución ${ }^{31}$. Una vez se cumplan estas condiciones, atribuidas al contratista, se puede dar por terminado el contrato de forma anticipada por parte de la administración, sin desconocer la obligatoriedad que le asiste de velar por favorecer la continuidad y la terminación a entera satisfacción de los contratos encomendados a terceros. Es decir, permite después de la utilización de este instrumento jurídico reemplazar al contratista con el fin de garantizar el cumplimiento del bien o servicio a contratar ${ }^{32}$.

Según (Dávila, 2016) la caducidad es una potestad de que goza la entidad estatal para dar por terminado de manera anticipada un contrato por razones atribuibles en un todo al contratista. A pesar que el efecto que subyace en una declaratoria tal es la ruptura del vínculo contractual, debemos advertir que la finalidad que persigue no es la simple terminación del contrato, sino muy por el contrario la opuesta, esto es la ejecución del contrato. En efecto, esta medida está concebida para favorecer la continuidad y la conclusión satisfactoria del objeto contractual para lo cual la ley le permite a la entidad remover el obstáculo que impide esa conclusión, cual es la actitud francamente desdeñada del contratista, con el fin de vincular a otro que satisfaga plenamente las prestaciones incumplidas.

Por otra parte, siguiendo con la Jurisprudencia del (Consejo de Estado, expediente: 16075, 2008), reiteró que la administración está habilitada para declarar la caducidad del contrato a través de un acto administrativo debidamente motivado, como lo establece el artículo 18 de la Ley $\mathrm{N}^{\circ}$ 80, 1993, siempre y cuando se cumplan los siguientes requisitos: (i) un

\footnotetext{
31 Según (Charris Benedetti \& Llamas Foliaco, 2016) El manejo del riesgo de incumplimiento atribuible a las características de los proveedores en la contratación pública en Colombia se limita a la exigencia de garantías, medidas contractuales de presión o la implementación de cláusulas exorbitantes al derecho común.

${ }^{32}$ La caducidad, puede ser aplicada por la entidad contratante cuando el contratista haya incumplido las obligaciones del contrato y es por esto que la caducidad lleva en si el carácter de sanción (Arango y García, 2004, p.23). Teniendo en cuenta que "la prevalencia del interés público impone que el ordenamiento jurídico le confiera a la administración pública una potestad exorbitante para asegurar el efectivo cumplimiento de las obligaciones del contratista, que se puede denominar potestad sancionadora" (Escobar, 2003, p.345).
} 
incumplimiento de las obligaciones a cargo del contratista; (ii) que el incumplimiento afecte de manera grave y directa la ejecución del contrato; (iii) y, que dicho incumplimiento evidencie que puede conducir a la paralización del contrato. Así mismo la referida sentencia agregó que al declarar la caducidad se generan cinco consecuencias jurídicas: (i) dar por terminado el contrato sin que se indemnice al contratista; (ii) ordenar la liquidación de éste en el Estado en que se encuentre; (iii) hacer exigible las garantías por configuración del siniestro del incumplimiento; (iv) hacer efectiva la cláusula penal pecuniaria; (v) y la inhabilitación del contratista para contratar con el Estado por el término de cinco años. Igualmente, el Consejo de Estado recordó que el límite temporal para declarar la caducidad del contrato solo puede ser durante el plazo de ejecución de éste mientras se encuentra vigente y no durante su etapa de liquidación, porque en la etapa de liquidación no es posible que se presente un incumplimiento de las obligaciones del contratista que pueda llevar a la paralización del servicio ${ }^{33}$.

En conclusión, una vez se declara la caducidad del contrato, por alguna de las consecuencias ya enunciadas, se ocasiona la inhabilidad para contratar, por los perjuicios generados a la entidad estatal por el incumplimiento de las obligaciones. Así surge la posibilidad de hacer efectiva la cláusula penal pecuniaria para estimar los perjuicios que se han ocasionado, ahora bien, si los perjuicios reales superan la estimación contenida en la cláusula penal pecuniaria, su reconocimiento solo se puede hacer por vía judicial.

\footnotetext{
${ }^{33}$ (Consejo de Estado, expediente 29028, 2014): Puesto que, la liquidación del contrato “(...) está instituida para efectuar un balance del estado en que quedaron los derechos y obligaciones de las partes y un corte económico de cuentas, declararse a paz y salvo en relación con las mismas y, por ende, para extinguirlo y no para sancionar al contratista por posibles incumplimientos en que haya incurrido en el plazo de ejecución cuando éste ya se encuentre terminado".
} 


\subsubsection{Reversión}

La cláusula de Reversión puede ser definida como: “una cláusula contractual propia de los contratos de concesión administrativa, en virtud de la cual el particular se obliga, a favor de la administración pública, a entregarle, a título de propiedad, sin que exista, deber de erogación de ninguna clase por parte de ésta, todos los elementos, bienes y elementos que se encuentran afectados a la explotación del bien o del servicio entregado en concesión por la administración respecto de los cuales se haya producido la amortización y también a devolverle los bienes recibidos de la administración a título de mera tenencia, junto con las mejoras incorporadas a estos bienes" (Santos, 2010, p.469).

Teniendo en cuenta esta definición se puede colegir que la reversión, según la (Real Academia Española, 2013) la reversión es la acción y efecto de revertir, y revertir, significa volver una cosa a la propiedad que tuvo antes o pasar a un nuevo dueño. Otra definición podría considerarse como una potestad excepcional en los contratos estatales que se hace efectiva a partir de la terminación de la vigencia del denominado contrato de concesión. Sobre esta sola tipología contractual el legislador colombiano ha dispuesto que la entidad estatal concedente por disposición legal se hace dueña de las obras, los equipos que se han utilizado en la operación, sin tener que pagar o reconocer a la otra parte, denominada concesionario, ya que se infiere que dentro de la estructura de costos por haber tenido la oportunidad de explotar por determinado tiempo un bien o servicio entregado en concesión por el Estado pudo recuperar el valor de lo invertido de esos bienes junto con la utilidad esperada. Esta cláusula de reversión por mandato expreso de la ley debe estar incluida en los contratos de explotación y concesión de bienes estatales ( Escola, 1979). 
En cuanto a la aplicación de la cláusula de reversión sin compensación es importante que se armonice la aplicación de la cláusula, en cuanto a que debe estar antecedida por una interpretación que armonice tanto el interés público como el derecho de dominio del particular. (Bohórquez, 2002) Por tanto considera que la reversión comprenderá exclusivamente los bienes necesarios para la prestación de servicio público, en tanto esa ejecución lo exija, y, en caso de duda sobre ese extremo concreto, sobre esa determinada situación de hecho, la interpretación deberá ser siempre a favor del concesionario, es decir, a favor de su derecho de propiedad, que no habrá que perder, sin ser adecuadamente indemnizado. (Escola, 1979).

Teniendo en cuenta lo enunciado en la regulación normativa ${ }^{34}$, se debe inferir que para hacer la cesión de las obras de los bienes y/o equipos utilizados en la concesión la reversión no tiene como condición estar sujeta a una condición resolutoria (Corte Constitucional, expediente D-8699, 2012) $)^{35}$, ya que "la transmisión de los bienes afectos al contrato pasan a manos del concedente a la extinción del término contractual, no es menos cierto que dicha transferencia no opera gratuitamente, pues la eficacia jurídica del plazo pactado está en permitir la amortización de la inversión" (Gutiérrez, 2015 citado por Escobar, 2003).

Al definir la cláusula de reversión, el (Consejo de Estado, expediente 30114, 2005) se ha pronunciado frente a este instrumento jurídico y ha mantenido la congruencia de criterios con relación al definido por la (Corte Constitucional, expediente: 1064, 1996) declaró la

\footnotetext{
${ }^{34}$ La regulación normativa frente a esta facultad exorbitante de la reversión de la Ley N ${ }^{\circ} 80$, 1993 en el Artículo 19 plantea lo siguiente: - De la Reversión. En los contratos de explotación o concesión de bienes estatales se pactará que, al finalizar el término de la explotación o concesión, los elementos y bienes directamente afectados a la misma pasen a ser propiedad de la entidad contratante, sin que por ello ésta deba efectuar compensación alguna.

${ }^{35}$ Finalmente, la jurisprudencia constitucional (Consejo de Estado, expediente: 26101, 2010) ha precisado que el contrato de concesión, por su finalidad, involucra la cláusula de reversión, así las partes no la pacten. Según esta cláusula, al finalizar el contrato, los elementos y bienes afectados para su desarrollo, se vuelven de propiedad de la entidad contratante, sin necesidad de remuneración adicional (Artículos 14.2 y 19 de la Ley $\left.\mathrm{N}^{\circ} 80,1993\right)$. Por el contrario, antes de que termine el contrato, el concesionario mantiene el control y el derecho de uso de los bienes afectados por el contrato.
} 
exequibilidad del artículo 19 de la Ley $\mathrm{N}^{\circ}$ 80, 1993 pues concluyó que (i) la cláusula de reversión es de la esencia del contrato de concesión y (ii) no es una expropiación sin indemnización porque el precio de esos bienes es pagado por el Estado en el precio del contrato.

Otro concepto ampliado por el Consejo de Estado define la reversión como un fenómeno que ocurre a la terminación normal o anormal de algunos contratos del Estado, particularmente de los contratos de concesión, que se explica por la índole del objeto del contrato (...) es norma de orden público, a la cual los gobernantes o la administración no pueden renunciar" (Consejo de Estado, expediente: 30114, 2005).

En pocas palabras, la reversión en los contratos de concesión, los concesionarios están obligados a transmitir el dominio de los bienes de ejecución del contrato al contratante, es decir que lo faculta para disponer de su propiedad, presuntamente para mantener el equilibrio contractual (Gutiérrez, 2015) ${ }^{36}$.

En conclusión el concesionario que celebra un contrato con una entidad pública para la operación, explotación, organización o gestión de un servicio u obra, asume por su cuenta y riesgo el éxito o el fracaso de su gestión, teniendo en cuenta que debió prever un modelo financiero para hacer viable el negocio, teniendo en cuenta las inversiones que se compromete a desarrollar y sabiendo de antemano que después de finalizado el plazo de vigencia del contrato debe otorgar la propiedad a la entidad pública contratante.

\footnotetext{
36 "Si bien la reversión en los contratos de concesión y explotación de bienes estatales se halla inmersa en las licitaciones de adjudicación, hace parte de las condiciones de dichos contratos, no debe entenderse esta como una expresión de partes, toda vez que no se garantiza la bilateralidad ni la voluntad de las mismas"(Gutiérrez, 2015, p.108). Basta retomar nuestro ordenamiento civil colombiano, que para efectos de contratos los sopesa en la buena fe y la igualdad de condiciones. Se trata entonces de una inclusión unilateral de orden legal que vicia la imparcialidad que debe reinar en este tipo de contratos.
} 


\section{CAPÍTULO II}

\section{Desarrollo normativo, doctrinal, jurisprudencial y derecho comparado (Ecuador) de la liquidación unilateral en los contratos interadministrativos}

\subsection{De la liquidación por mutuo acuerdo y liquidación unilateral}

Una primera definición de liquidación según la (Real Academia de la Lengua, 2013) hace referencia a saldar, pagar enteramente una cuenta, es así, que dentro de un contexto general encontramos que, entendida la liquidación como la rendición mutua de cuentas entre las partes contratantes, y en atención al hecho de que suscrita el acta contentiva del acuerdo de voluntades al respecto, ella veda la promoción jurisdiccional de pretensiones contractuales sobre la materia en tanto que se convierte en una especie de paz y salvo, con apoyo en esa circunstancia, estimamos que la totalidad de las relaciones negociables del Estado deben liquidarse para efectos de determinar el real estado prestacional de la entidad respecto de los contratos celebrados (Rico, 2004)

Frente a la liquidación de los contratos estatales, en principio se debe advertir que el momento hito en el que se puede hacer uso de esta herramienta jurídica, se da en la etapa post-contractual del proceso de contratación. En esta etapa lo que se busca, como lo dice (Dávila 2016, p.556) "es una rendición final de cuentas para saber quién le debe a quién y cuánto", es decir, se hace una revisión a las obligaciones contraídas respecto a los resultados financieros, contables, jurídicos y técnicos para poder declararse a paz y salvo las obligaciones adquiridas dentro del mismo. Como diría (Expósito, 2013) es un acto final en el desarrollo de la relación jurídica bilateral entre la administración y el contratista que permite evidenciar el estado de 
ejecución del objeto pactado y todas las prestaciones y obligaciones anexas al mismo por cada una de las partes involucradas en el contrato. Es en esta instancia donde se hacen los ajustes a que haya lugar e igualmente se reconocen derechos y obligaciones que surgen como resultado de la ejecución contractual, los cuales quedan plasmados mediante acuerdos, conciliaciones y transacciones o incluso en el mismo documento de liquidación contractual.

Esa finalidad a la que le apunta la liquidación del contrato estatal, se entiende como un ajuste final de cuentas en el que (Rodríguez 2013, p.463) expone "corresponde al balance, finiquito o corte de cuentas que realizan y acogen de manera conjunta las partes del respectivo contrato, por tanto, esta modalidad participa de una naturaleza eminentemente negocial o convencional". Es decir, se trata del balance de las obligaciones del contrato y su cumplimiento, razón suficiente para no prescindir de su acatamiento. En el mismo sentido, la jurisprudencia sostiene que la razón de ser de la liquidación del contrato no es otra que servir a las partes para que "definan sus cuentas, decidan en qué estado quedan después de la ejecución de aquel, (...) decidan todas las reclamaciones a que ha dado lugar la ejecución del contrato" (Hernández, 1997).

(Lamprea, 2007) destaca determinados fines de la liquidación derivados del procedimiento dispuesto en la ley: 1. Efectuar el ajuste de cuentas de lo que las partes estipularon cumplir; 2. Hacer devoluciones recíprocas de lo entregado para fines del contrato y no empleado en la obra, y finalmente. 3. Confeccionar, discutir y aprobar el acta de liquidación, fijando la cuenta final del contrato con cantidad clara, expresa y exigible para que obre como título de cobro ejecutivo de lo que la entidad contratante o el contratista salgan a deberle al otro, por causa del contrato. 
Así mismo el (Consejo de Estado, expediente 24510, 2013) advierte que de este instrumento jurídico, en el corte de cuentas en las liquidaciones ${ }^{37}$ de los contratos estatales, pueden surgir acuerdos y desacuerdos por situaciones acaecidas en la ejecución del contrato, que podrían quedar consignados en la respectiva acta de liquidación, para posteriormente en otro escenario, como lo es acudir a la jurisdicción, se puedan rebatir las correspondientes reclamaciones ante el juez del contrato ${ }^{38}$.

Según (Dávila, 2016) en las liquidaciones de los contratos pueden suceder circunstancias como la disparidad de criterios al momento de hacer el cierre definitivo de la relación contractual, teniendo en cuenta que podría consistir en que si bien el objeto se ha cumplido, existen algunas fallas menores u obligaciones insatisfechas o imperfectas cumplidas. En tal evento, se puede optar por permitir los arreglos faltantes, que parece ser lo más conveniente, o, lo que se observa cómo proceder habitual de las entidades, evaluar la naturaleza de lo incumplido para efectos de efectuar los respectivos descuentos al valor del contrato.

Cuando se está haciendo el corte de cuentas en la liquidación del contrato, que el objeto ejecutado concluya, con las obras acometidas o los servicios prestados y los bienes entregados no reúnan las exigencias estipuladas en un plano, igualmente teórico, podrían sucederse dos situaciones:

\footnotetext{
37،El Estatuto General de Contratación de la administración Pública, contenido en la Ley N 80, 1993, establece la obligación de liquidar los contratos de tracto sucesivo, de aquellos cuya ejecución o cumplimiento se prolongue en el tiempo y de aquellos que lo requieran, según su objeto, naturaleza y cuantía. La partes deben en esta etapa acordar los ajustes, revisiones y reconocimientos a que haya lugar y en la correspondiente acta hacer constar los acuerdos, conciliaciones y transacciones a que llegaren para poner fin a las divergencias presentadas y poder así declararse a paz y salvo. Esta ley prevé, así mismo, distintos procedimientos para tal liquidación, a saber: a) La liquidación voluntaria o de común acuerdo entre las partes contratantes. b) Liquidación unilateral por la administración. c) Liquidación por vía judicial. e) En el evento en que no se proceda a la liquidación dentro de los términos previstos por el artículo 60 citado y transcurran los dos años "siguientes al incumplimiento de la obligación de liquidar", sobre caducidad de la acción contractual a que se refiere el C.C.A., artículo numeral 10, letra d), la administración pierde la competencia para proceder a la misma".

${ }^{38}$ (Rico, 2015) afianza tales planteamientos asegurando que: “...la liquidación del contrato no es un simple formato en el que la administración detalla los aspectos generales de la relación negocial, tales como partes, plazo, valor, etc., con un indicativo final de los valores que deben pagarse o reconocerse las partes. La filosofía que orienta esta institución, es lograr una verdadera radiografía de lo ocurrido, dejando expresa constancia no solo de los acuerdos, sino especialmente de los desacuerdos, pues estos últimos ordinariamente tipifican la alteración del equilibrio contractual que han de reclamarse en vía jurisdiccional”.
} 
La primera, que el contratista acepta los reparos formulados, en cuyo caso se consignarán en el acta de liquidación, lo que serviría de título para el cobro de la garantía única de cumplimiento, la segunda, que genere inconformidad con el contratista, quien alega la existencia, por ejemplo, de circunstancias ajenas a él como causantes del incumplimiento e incluso atribuibles a la entidad. En este evento, también pueden acontecer dos circunstancias. En virtud de la primera, las partes llegan a acuerdos parciales por lo que consignan cada una sus planteamientos, con lo cual quedará en manos del juez la resolución del conflicto en lo no resuelto y abre la puerta a la liquidación unilateral parcial a cargo de la entidad estatal contratante. Lo importante a destacar es que en esta instancia de liquidación, que presupone la extinción del vínculo, no puede hacerse uno de ningún poder excepcional de los previstos en los artículos 16 al 19 de la Ley $\mathrm{N}^{\circ}$ 80, 1993. Esta posición que niega una facultad tal se inspira en el respeto de elementales principios de equidad y buena fe que siempre deben presidir la contratación, con mayores veras la estatal. Una cosa es que las entidades puedan hacer uso de la facultad, por ejemplo, de caducidad antes de la iniciación de la fase de liquidación (Dávila, $2016)^{39}$.

La segunda situación que puede plantear, nace del desacuerdo absoluto del contratista y de su negativa a avalar y aceptar la liquidación propuesta por la entidad, en cuyo evento se abre camino la liquidación unilateral del contrato (Dávila, 2016).

Frente a la figura de la liquidación en los contratos estatales se puede señalar que este instrumento jurídico data del año 1976 con la expedición del Decreto $\mathrm{N}^{\circ} 150^{40}$, posteriormente el

\footnotetext{
${ }^{39}$ Vale decir cuando el contrato todavía está en ejecución y otra bien diferente que concurra con el contratista con la intención de liquidar el contrato de común acuerdo pero que en vista de los desacuerdos aproveche la inexistencia real del acto que solo se materializa al final de la fase, para expedir el acto de caducidad (Dávila, 2016).

${ }^{40}$ Artículo 11. De las sanciones a los contratos celebrados contra expresa prohibición. $<$ Derogado por el Decreto 301 del Decreto 222 de 1983>La contravención de las anteriores prohibiciones dará lugar a que el representante legal de la respectiva entidad dé por terminado el
} 
Decreto $\mathrm{N}^{\circ} 222,1983^{41}$. En estos primeros decretos se tiene como antecedente la regulación de esta figura objeto de estudio, en la que posteriormente para el año de 1993, en la ley 80, se terminó de regularizar la liquidación de los contratos, concretamente en el artículo $60^{42}$, teniendo en cuenta tres condiciones: en primer lugar, la procedencia de la liquidación no es connatural a la totalidad de los contratos estatales sino solo a determinada tipología contractual, es decir, aquellos que por su naturaleza requerían de este tipo de liquidaciones, y mencionó los de tracto sucesivo, los que tengan ejecución prolongada en el tiempo, y así mismo los reglados en el artículo 16, cuando se hace alusión a la liquidación de los contratos. Al utilizar la potestad unilateral de modificación el contratista renuncia al contrato porque hubiese una modificación superior al $20 \%$ y en esas condiciones no tuviere interés en el contrato.

contrato y proceda a su liquidación en el estado en que se encuentre, sin que haya lugar a reconocimiento o pago de indemnización alguna.

A partir de la fecha de terminación, la Contraloría General de la República se abstendrá de autorizar cualquier giro o pago para el contrato terminado, salvo lo que resulte de la liquidación.

Si por su celebración se causaren perjuicios a la entidad contratante serán responsables solidariamente el contratista y el funcionario o funcionarios que lo hubieren celebrado. En todo caso quedarán a salvo las sanciones penales a que hubiere lugar.

${ }^{41}$ Liquidación de los contratos. Artículo 287. De los casos en que procede la liquidación.- (Derogado por el artículo 81 de la ley N 80, 1993). Deberá procederse a la liquidación de los contratos en los siguientes casos:

1. Cuando se haya ejecutoriado la providencia que declaró la caducidad.

2. Cuando las partes den por terminado el contrato por mutuo acuerdo, lo cual podrá hacerse en todos los casos en que tal determinación no implique renuncia a derechos causados o adquiridos en favor de la entidad contratante.

3. Cuando se haya ejecutoriado la providencia judicial que lo declare nulo.

4. Cuando la autoridad competente lo declare terminado unilateralmente conforme al artículo 19 del presente estatuto.

Además de los casos señalados, y si a ello hubiere lugar, los contratos de suministros y de obras públicas deberán liquidarse una vez que se hayan cumplido o ejecutado las obligaciones surgidas de los mismos.

Artículo 288. De las personas que deben efectuar la liquidación. <Derogado por el artículo 81 de la ley $\mathrm{N}^{\circ} 80,1993>$. Cuando a ello hubiere lugar, deberán liquidar los contratos el jefe de la entidad contratante, o quien él encargue por resolución; el contratista y en el evento en que éste se negare, el interventor, o quien haga sus veces. El acta de liquidación se pondrá a disposición de la Contraloría General de la República, para efectos del control posterior.

Artículo 289. Del contenido de la liquidación. <Derogado por el artículo 81de la ley $\mathrm{N}^{\circ}$ 80, 1993>. Las diligencias de liquidación, que siempre constará en: actas, determinarán las sumas de dinero que haya recibido el contratista y la ejecución de la prestación a su cargo.

Con base en dichas actas se determinarán las obligaciones a cargo de las partes, teniendo en cuenta el valor de las sanciones por aplicar, o las indemnizaciones a favor del contratista, si a ello hubiere lugar, todo de conformidad con lo acordado en el respectivo contrato.

Si no hubiere acuerdo para liquidar un contrato, se tendrá por firme la liquidación presentada por la entidad contratante, la cual se expedirá mediante resolución motivada que estará sujeta a los recursos ordinarios por la vía gubernativa.

El acta final de liquidación, que deberá ser aprobada por el jefe de la entidad contratante, si él no hubiere intervenido, presta mérito ejecutivo ante la jurisdicción coactiva contra el contratista y su garante en cuanto de ella resultaron obligaciones económicas a su cargo.

${ }^{42}$ VI De la liquidación de los contratos. Artículo 60.-De Su Ocurrencia y Contenido. Modificado por el Artículo 217, Decreto Nacional 019 de 2012. Los contratos de tracto sucesivo, aquéllos cuya ejecución o cumplimiento se prolongue en el tiempo y los demás que lo requieran, serán objeto de liquidación de común acuerdo por las partes contratantes, procedimiento que se efectuará dentro del término fijado en el pliego de condiciones o términos de referencia o, en su defecto, a más tardar antes del vencimiento de los cuatro (4) meses siguientes a la finalización del contrato o a la expedición del acto administrativo que ordene la terminación, o a la fecha del acuerdo que la disponga. Inciso derogado por el Artículo 32 de la Ley 1150 de 2007, excepto el texto subrayado.

También en esta etapa las partes acordarán los ajustes, revisiones y reconocimientos a que haya lugar.

En el acta de liquidación constarán los acuerdos, conciliaciones y transacciones a que llegaren las partes para poner fin a las divergencias presentadas y poder declararse a paz y salvo.

Para la liquidación se exigirá al contratista la extensión o ampliación, si es del caso, de la garantía del contrato a la estabilidad de la obra, a la calidad del bien o servicio suministrado, a la provisión de repuestos y accesorios, al pago de salarios, prestaciones e indemnizaciones, a la responsabilidad civil y, en general, para avalar las obligaciones que deba cumplir con posterioridad a la extinción del contrato. 
En segundo lugar, mencionó la necesidad de liquidación del contrato, a propósito de la expedición del decreto de caducidad y en los casos de nulidad absoluta -artículo 45-. Finalmente, con relación al contenido, precisó la Ley N 80, 1993 que en la liquidación deberían hacerse los ajustes, las revisiones y reconocimientos a que hubiere lugar a favor de las partes, en el entendido de que precisaba hacerse un análisis de lo que había pasado en el contrato, revisar cuáles eran las obligaciones, cuál el presupuesto, cuál la ejecución, cuál el costo final o si hubo, por alguna razón, necesidad de efectuar ajustes al desarrollo del contrato para finiquitar las cuentas entre las partes. Cabe resaltar que esta ley fue modificada por la Ley $\mathrm{N}^{\circ} 1150$, 2007, la cual definió el plazo para la liquidación de los contratos estatales en el artículo 11, e igualmente fue modificada por el artículo 217 del Decreto $N^{\circ}$ 019, 2012 (Vargas, 2016) $^{43}$.

La liquidación de los contratos estatales ${ }^{44}$ puede darse de varias formas dependiendo de las circunstancias a las que lleguen contratante y contratista, teniendo en cuenta que puede en principio darse de forma bilateral o unilateral según sea el caso. No obstante lo anterior, existen excepciones en la forma como se pueden liquidar los contratos teniendo en cuenta que en el período de ejecución de un contrato se pueden presentar liquidaciones parciales, de lo cual se infiere que la liquidación y la terminación no son excluyentes la una de la otra, es decir, pudiendo existir liquidación parcial aunque no se haya llegado a la terminación del contrato, sin

\footnotetext{
${ }^{43}$ Artículo 217. De la ocurrencia y contenido de la liquidación de los contratos estatales.

El artículo 60 de la Ley $N^{\circ} 80,1993$, modificado por el artículo 32 de la Ley $\mathrm{N}^{\circ} 1150,2007$ quedará así:

"Artículo 60 De la ocurrencia y contenido de la liquidación. Los contratos de tracto sucesivo, aquellos cuya ejecución o cumplimiento se prolongue en el tiempo y los demás que lo requieran, serán objeto de liquidación.

También en esta etapa las partes acordarán los ajustes, revisiones y reconocimientos a que haya lugar.

En el acta de liquidación constarán los acuerdos, conciliaciones y transacciones a que llegaren las partes para poner fin a las divergencias presentadas y poder declararse a paz y salvo.

Para la liquidación se exigirá al contratista la extensión o ampliación, si es del caso, de la garantía del contrato a la estabilidad de la obra, a la calidad del bien o servicio suministrado, a la provisión de repuestos y accesorios, al pago de salarios, prestaciones e indemnizaciones, a la responsabilidad civil y, en general, para avalar las obligaciones que deba cumplir con posterioridad a la extinción del contrato.

La liquidación a que se refiere el presente artículo no será obligatoria en los contratos de prestación de servicios profesionales y de apoyo a la gestión."

${ }^{44}$ Frente a la competencia para expedir esta clases de actos donde se liquidan los contratos estatales (Dávila 2016) señala la responsabilidad en cabeza del jefe o representante legal de la entidad o del funcionario delegatario, para el caso de las entidades estatales, y del representante legal del contratista.
} 
perjuicio de lo que no se liquidó, que podría seguir vigente y en ejecución en el marco de un contrato estatal. Otra excepción a la regla de la liquidación de los contratos estatales es aquella en la que el tipo de contrato no tiene, según la ley, la obligatoriedad de liquidarse, como lo es el contrato de prestación de servicios.

\subsection{Algunos aspectos relevantes de la liquidación unilateral en los contratos estatales}

Frente a la liquidación unilateral ${ }^{45}$ podemos decir que es una herramienta jurídica que en determinadas circunstancias puede ser empleada por las entidades estatales contratantes, con la finalidad de tomar decisiones respecto de los resultados y las obligaciones contraídas en el contrato estatal, sin necesidad de contar con la voluntad o con el consentimiento del respectivo contratista, después de haber intentado un acuerdo, y que el mismo haya sido fallido. Así mismo, se debe tener en cuenta que esta figura jurídica subsidiaria a la liquidación bilateral se puede utilizar siempre y cuando se cumpla con los eventos, las circunstancias y las exigencias establecidos para esos casos en la ley ${ }^{46}$.

Según (Dávila 2016, p. 766) “en la liquidación unilateral el legislador ha otorgado plenas facultades a las entidades estatales para que después de haber intentado por común acuerdo hacer una liquidación del contrato, la administración unilateralmente pueda a su entender hacer los reconocimientos a que haya lugar, sin perjuicio que pueda agotar la vía gubernativa y ser demandable el acto administrativo proferido por la entidad estatal ante la

\footnotetext{
45، "La validez del acto de liquidación está supeditada a que la entidad haya solicitado la presencia del contratista con el fin de liquidar el contrato, la expedición del acto si un proceso previo de invitación, genera, entonces, la anulabilidad de tal acto por abuso de poder o vionlacion del debido proceso" (Dávila, 2016, p.773).

${ }^{46}$ La Sección Tercera del (Consejo de Estado expediente 28881, 2014) se ha pronunciado sobre el carácter subsidiario de la liquidación unilateral y ratifica lo que la doctrina también ha pronunciado en lo siguiente: "El carácter subsidiario que le corresponde a la liquidación unilateral, respecto de la bilateral o conjunta, lo evidencia la norma legal que la consagra en cuanto supedita su procedencia a cualquiera de las siguientes hipótesis fácticas: i) que el contratista particular no se presente a la liquidación, con lo cual imposibilita la realización de una liquidación bilateral o conjunta, o ii) que las partes no lleguen a acuerdo sobre el contenido de la liquidación, cuestión que igualmente impide la adopción conjunta del respectivo corte de cuentas". Así pues, sólo si se configura una de las circunstancias enunciadas, la Entidad Estatal quedará facultada para practicar la liquidación correspondiente de manera directa y unilateral, caso en el cual procederá a adoptarla mediante la expedición de un acto administrativo debidamente motivado, el cual será pasible del recurso de reposición en vía gubernativa".
} 
jurisdicción de lo contencioso administrativo".

Este acto administrativo expedido por la administración debe tener en cuenta los plazos establecidos en el artículo 11 de la Ley $\mathrm{N}^{\circ} 1150,2007^{47}$. Así mismo los contratistas tendrán derecho a efectuar salvedades a la liquidación por mutuo acuerdo, y en este evento la liquidación unilateral solo procederá con relación a los aspectos que no hayan sido objeto de acuerdo.

Frente a esta norma que reglamenta los plazos de las liquidaciones se concluye que no solo se adquiere competencia para liquidar unilateralmente cuando se haya agotado la liquidación de común acuerdo, sino que la misma ley deja la puerta abierta para que la administración busque siempre la liquidación de común acuerdo entre las partes que suscribieron el contrato estatal ${ }^{48}$.

En efecto, surge la inquietud de si en los contratos y convenios interadministrativos, cuando la norma exige que se deba excluir la utilización de las cláusulas excepcionales, ello implica la prohibición de utilización de cualquier otra clase de poderes unilaterales (Rengifo García, 2014), como es el caso de la liquidación unilateral.

\footnotetext{
${ }^{47}$ Artículo 11. Del plazo para la liquidación de los contratos. La liquidación de los contratos se hará de mutuo acuerdo dentro del término fijado en los pliegos de condiciones o sus equivalentes, o dentro del que acuerden las partes para el efecto. De no existir tal término, la liquidación se realizará dentro de los cuatro (4) meses siguientes a la expiración del término previsto para la ejecución del contrato o a la expedición del acto administrativo que ordene la terminación, o a la fecha del acuerdo que la disponga.

En aquellos casos en que el contratista no se presente a la liquidación previa notificación o convocatoria que le haga la entidad, o las partes no lleguen a un acuerdo sobre su contenido, la entidad tendrá la facultad de liquidar en forma unilateral dentro de los dos (2) meses siguientes, de conformidad con lo dispuesto en el artículo 136 del C.C.A.

Si vencido el plazo anteriormente establecido no se ha realizado la liquidación, la misma podrá ser realizada en cualquier tiempo dentro de los dos años siguientes al vencimiento del término a que se refieren los incisos anteriores, de mutuo acuerdo o unilateralmente, sin perjuicio de lo previsto en el artículo 136 del C.C.A.

${ }^{48} \mathrm{Al}$ respecto, vale la pena señalar lo señalado por el Consejo de Estado al referirse dentro del marco conceptual de la etapa de liquidación unilateral en los contratos estatales en lo siguiente: "la actividad de la administración en la liquidación del contrato no constituirá siquiera un poder exorbitante pues no tiene la finalidad indicada, pero suele también dársele esa calificación solo por el carácter de unilateral que puede tener cuando aquella procede a adelantarla cuando el contratista no colabora para llevarla a cabo o habiéndolo hecho no aprueba las conclusiones a las que se llega. Pero ese poder no puede llegar hasta señalar la responsabilidad y las consecuencias indemnizatorias que se deriven, pues esta misión le corresponde es a los jueces" (Dávila, 2016).
} 
Según (Pemberthy, 2015) señala que: "la liquidación como una obligación que debe ser realizada por la administración con el objeto de afirmar la recta gestión y el cuidado de lo público en toda su dimensión. Sostenemos que en los contratos la liquidación bilateral y unilateral se convierte en una obligación legal y de gestión para ambas partes, toda vez que están obligadas a cuidar y velar por el interés general. No pensamos, como la mayoría de la doctrina y la jurisprudencia, que la liquidación unilateral no se puede imponer al contratista por ser una entidad de derecho público (Criterio Orgánico)”.

En conclusión, frente a la responsabilidad de cada una de las partes del contrato una vez culmine el plazo de ejecución del mismo, de liquidar los contratos estatales, y las partes establezcan, con fundamento en el desarrollo del contrato, las acreencias a favor o en contra de cada uno, (Hernández Silva, 2009), en la práctica debería estipularse de carácter obligatorio el suscribir acta de liquidación, así fuese para plasmar que no hubo desacuerdos entre las partes. Lo que de alguna forma se buscaría es que haya un balance y un control sobre las obligaciones del contrato, lo que se ejecutó, lo que posiblemente quedó inconcluso y así se ahorraría la administración pública el tener que finiquitar cientos de contratos estatales que quedan a la postre en contravía del interés público, incluso generando detrimento patrimonial por no tener el carácter obligatorio y el deber de cuidado en la etapa post-contractual.

Por último cabe resaltar que frente a la liquidaciones unilaterales de los contratos interadministrativos la posición de (Pemberthy, 2015) cuando concluye que el contratista, como ente público, no puede ampararse en el argumento de no haber sido citado o convocado o haber estado en desacuerdo con la liquidación, asume una posición pasiva y da la espalda a los intereses públicos, en clara omisión de los deberes constitucionales. La defensa de lo público 
implica deberes para ambas partes del contrato. No se puede cerrar esta oportunidad a la Administración (ambos son Administración) y someterlos a la vía judicial que, en últimas, es el mismo Estado, mediante la vía de la función judicial. Así, debe realizarse la liquidación unilateral y ambas partes pueden realizarla mediante acto administrativo, en razón del ejercicio de su propia competencia.

No obstante lo anterior para (Cohecha León, 2015), la liquidación de los contratos estatales implica que la Administración Pública goza de una prerrogativa o potestad excepcional, en relación con el derecho privado, que no fue incluida como cláusula excepcional. Empero, huelga precisa que no todos los eventos de liquidación, por terminación normal o anormal del contrato, son una potestad excepcional, solo lo es la liquidación unilateral pues la liquidación bilateral no denota el ejercicio de ninguna facultad de la que no gozan los particulares.

\subsection{Análisis legislativo comparado de liquidaciones unilaterales en los contratos}

\section{interadministrativos en la República de Ecuador}

Es necesario contar con un marco referencial de otros países, relacionado con el instrumento jurídico que es objeto de investigación, por lo tanto es importante señalar lo que acontece respecto a la legislación ecuatoriana ${ }^{49}$, no $\sin$ antes precisar que en el proceso de ejecución contractual de los contratos interadministrativos, frente al contratista público, se lleva a cabo el mismo procedimiento y se parte del mismo marco de acción que compete a un contratista privado, es decir, se utiliza el régimen previsto para administrar, terminar, recibir y liquidar

\footnotetext{
${ }^{49}$ El Reglamento a la LOSNCP establece que se debe suscribir un acta de entrega de recepción definitiva que dé cuenta de los antecedentes, condiciones generales de ejecución, condiciones operativas, liquidación económica, liquidación de plazos, constancia de la recepción, cumplimiento de las obligaciones contractuales, reajustes de precios pagados, de ser el caso, o pendientes de pago, y cualquier otra circunstancia que se estime necesaria. Con la suscripción de este documento en el que se consignarán estos datos y una vez que la entidad contratante cancele los valores adeudados, se dará por finalizada la relación contractual generada en el contrato. Esto no obstante, la responsabilidad técnica que los contratistas mantienen sobre su obra, el servicio o bien entregado. Esta forma de extinción de las obligaciones contractuales opera de la misma manera tanto en los contratos administrativos como en los interadministrativos (Moreno García, 2011).
} 
contratos (Moreno, 2011)

Sin embargo hay que advertir, respecto a la etapa de recepción y liquidación de los contratos estatales, que el mecanismo para hacerlo es mediante un acta en la que reposa la información del estado en que se cumplieron las obligaciones del contrato, el balance financiero y una evaluación del contrato. Este último hace un recuento de los aprendizajes que debe ser considerado para una futura compra que el Estado lleve a cabo.

En la liquidación del contrato estatal ${ }^{51}$, el legislador ecuatoriano obliga a la entidad pública a que, una vez se haya terminado el contrato, se lleve a cabo la recepción y liquidación parcial o definitiva dependiendo del contrato y las circunstancias, sin perjuicio de que en el evento de que el funcionario se abstenga de liquidar el contrato, podría ser sancionado por el Consejo de la Judicatura.

En el artículo 81 de la Ley de Contratación Pública del Ecuador se reglamenta la recepción y liquidación de los contratos e indica como debe llevarse a cabo la recepción del contrato, contenida en actas que se diferencian en recepción provisional, parcial, total y definitiva. Estas actas deben ser suscritas por el contratista y los integrantes de la comisión designada por la máxima autoridad de la entidad contratante o su delegado, conformada por el

\footnotetext{
${ }^{50}$ Ley de Contratación Pública del Ecuador Artículo 81.Clases de recepcióm (Reformado por el Artículo 21 de la Ley. s/n, R.O. 100-2S, 14$\mathrm{X}-2013)$.

${ }^{51}$ Sin embargo en relación a la liquidación de los contratos en Ecuador, hay una particularidad introducida en la legislación en cuanto a la posibilidad que tiene el contratista de presentar la liquidación a la entidad o en su defecto ante un juez, después de cumplido el término que tiene la entidad estatal para llevarlo a cabo. Ley de Contratación Pública del Ecuador Artículo 81. Clases de recepción (Reformado por el Artículo 21 de la Ley. s/n, R.O. 100-2S, 14-X-2013). En los contratos de adquisición de bienes y de prestación de servicios, incluidos los de consultoría, existirá una sola recepción, que se producirá de conformidad con lo establecido en el contrato y tendrá los efectos de recepción definitiva. "...En los contratos de ejecución de obra, así como en los contratos integrales por precio fijo existirán una recepción provisional y una definitiva".

Sin perjuicio de lo señalado en los incisos anteriores, en las contrataciones en que se pueda receptar las obras, bienes o servicios por etapas o de manera sucesiva, podrán efectuarse recepciones parciales. En los casos en los que ante la solicitud del contratista, la Entidad Contratante no formulare ningún pronunciamiento ni iniciare la recepción dentro de los períodos determinados en el Reglamento de esta Ley, se considerará que tal recepción se ha efectuado de pleno derecho, para cuyo efecto un Juez de lo Civil o un Notario Público, a solicitud del contratista notificará obligatoriamente que dicha recepción se produjo la negativa del funcionario será causal de sanción por parte del Consejo de la Judicatura. La recepción presunta definitiva producirá como único efecto la terminación del contrato, dejando a salvo los derechos de las partes a la liquidación técnico económica correspondiente. La entidad contratante declarará la recepción presunta a su favor, respecto de los contratistas de obras, adquisición de bienes o servicios, incluidos los de consultoría, en el caso de que éstos se negaren expresamente a suscribir las actas de entrega recepción previstas, o si no las suscribieren en el término de diez días, contado desde el requerimiento formal de la entidad contratante. La recepción presunta por parte de la entidad contratante, la realizará la máxima autoridad o su delegado mediante resolución motivada, que será notificada al contratista de conformidad con el procedimiento establecido en el Reglamento de esta Ley.
} 
administrador del contrato y un técnico que no haya intervenido en el proceso de ejecución del contrato (Subdirección General de Control, 2015).

Después del paso anterior, se debe hacer la liquidación del contrato, al respecto la Subdirección General de Control, 2015) indica que la liquidación económica contable del contrato se deja constancia de lo ejecutado, se determinan los valores recibidos por el contratista, los pendientes de pago o los que deben deducirle o deba devolver por cualquier concepto, aplicando los reajustes correspondientes y se hacen las compensaciones a que hubiere lugar.

La liquidación final será parte de la recepción definitiva. Los valores liquidados deberán pagarse dentro de los diez días siguientes a la liquidación; vencido el término causarán intereses legales y los daños y perjuicios que justificare la parte afectada.

Posteriormente, hay una fase post-contractual (Evaluación), que es la validación, aprendizaje y retroalimentación, se refiere a la verificación de cumplimiento de términos y garantías del procedimiento de contratación. Así como también a los mecanismos de aprendizaje institucional a través de informes de cierre de procedimientos, con la finalidad de que sirvan para nutrir los procesos futuros. (Subdirección General de Control, 2015).

En conclusión, frente a la forma como se liquidan los contratos estatales en Colombia y Ecuador hay una notable diferenciación, iniciando por el tratamiento que le da la entidad pública contratante a la entidad pública contratista, en donde claramente no se le reconocen prerrogativas por el hecho que en la relación contractual estén entre iguales. 


\subsection{Desarrollo jurisprudencial de la liquidación unilateral de los contratos, especialmente los contratos interadministrativos desde el año 2004}

Frente al desarrollo jurisprudencial que se ha venido decantando a través de reiteradas sentencias por parte del Consejo de Estado, en las que se ha pronunciado acerca de la liquidación unilateral en los contratos interadministrativos, se puede inferir que en el desarrollo de esta figura, no se ha tenido una posición pacífica frente a la utilización de este instrumento jurídico por parte de las entidades públicas, ya que este órgano de cierre en la jurisdicción de lo contencioso administrativo, en algunas sentencias citadas en este segmento, se puede evidenciar la evolución y los cambios de posturas que ha tenido en el tiempo.

Cabe advertir algunas diferenciaciones antes de citar la jurisprudencia, que hace (Díaz, 2013) entre las dos clases de liquidaciones que coexisten en las normas legales colombianas. En la bilateral hay un acta de convención y en la unilateral hay un acto administrativo pleno, o sea que en la liquidación unilateral se presenta una verdadera actuación de la Administración en ejercicio de su competencia y de manera exclusiva, que excluye a la otra parte del contrato de la decisión de la administración, proferida en ejercicio de potestad estatal expresa que le confiere la ley (Artículo 61 de la Ley $\mathrm{N}^{\circ}$ 80, 1993 ${ }^{52}$ ) para finiquitar el contrato. Es un acto administrativo, en cuanto constituye expresión de voluntad unilateral de la entidad estatal contratante en uso de función administrativa, que comporta al propio tiempo la utilización de una prerrogativa propia y exclusiva del Estado, dirigida a poner término a una determinada relación contractual. (Consejo de Estado, expediente 19333, 2002).

\footnotetext{
${ }^{52}$ Artículo 61. De la Liquidación Unilateral. Derogado por el artículo 32, Ley No 1150, 2007. Si el contratista no se presenta a la liquidación o las partes no llegan a acuerdos sobre el contenido de la misma, será practicada directa y unilateralmente por la entidad y se adoptará por acto administrativo motivado susceptible del recurso de reposición.
} 
Al respecto el Consejo de Estado en oportunidades anteriores, ha explicado la noción de la liquidación de los $\operatorname{contratos}^{53}$, sin embargo, en la sentencia del 20 de mayo de 2004, la Sala de lo Contencioso Administrativo, Sección Tercera ${ }^{54}$, sostuvo una postura controvertida al equiparar la liquidación unilateral de los contratos interadministrativos a las cláusulas excepcionales y, por consiguiente, planteó una discusión diferente que es objeto de controversia en este trabajo de investigación.

Así mismo, bajo ese panorama, el (Consejo de Estado, expediente 25.154. 2004) manifestó, para ese entonces, que lo contemplado en el artículo 14 de la Ley $\mathrm{N}^{\circ}$ 80, 1993, se hace extensivo también a los artículos 60 y 61 de la misma ley.

Es decir, el parágrafo del artículo 14 de la Ley $\mathrm{N}^{\circ} 80$, 1993, sobre los medios que pueden utilizar los entes estatales para el cumplimiento del objeto contractual, señala acerca de los contratos interadministrativos lo siguiente: “(...) se prescindirá de la utilización de las

\footnotetext{
53 "La liquidación final del contrato tiene como objetivo principal, que las partes definan sus cuentas, que decidan en qué estado queda después de cumplida la ejecución de aquél; que allí se decidan todas las reclamaciones a que ha dado lugar la ejecución del contrato, y por esa razón es ese el momento en que se pueden formular las reclamaciones que se consideren pertinentes. La liquidación finiquita la relación entre las partes del negocio jurídico, por ende no puede con posterioridad demandarse reclamaciones que no hicieron en ese momento (Consejo de Estado, expediente $\left.\mathrm{N}^{\circ} 10.608,1997\right)$ Este pronunciamiento fue recogido y reiterado por la misma Sección Tercera de la Sala de lo Contencioso Administrativo del (Consejo de Estado, expediente $\left.\mathrm{N}^{\circ} 11.101,1998\right)$

54،"En el ordenamiento legal aparece una restricción en los CONTRATOS INTERADMINISTRATIVOS para la utilización de poderes excepcionales y con estos el de liquidar unilateralmente el contrato porque tanto el contratante como el contratista son sujetos públicos, relación horizontal de la administración Estado que impide, de naturaleza, la imposición de decisiones unilaterales en el mundo de los negocios jurídicos a la contraparte que también es Estado. Y ello lo comprende así el (Consejo de Estado, Expediente 25.154, 2004) por la integración armónica que se da entre los artículos 14, 60 y 61 de la Ley $\mathrm{N}^{\circ} 80$, 1993. El parágrafo del artículo 14, sobre los medios que pueden utilizar las entidades estatales para el cumplimiento del objeto contractual, señala que en los contratos interadministrativos, entre otros, "se prescindirá de la utilización de las cláusulas o estipulaciones excepcionales". A su vez enlista como cláusulas excepcionales al derecho común las de terminación, interpretación y modificación unilaterales, de sometimiento a las leyes nacionales y de caducidad. El artículo 60 ibídem, sobre la ocurrencia y contenido de la liquidación del contrato, expresa que en los contratos de tracto sucesivo, aquéllos cuya ejecución o cumplimiento se prolongue en el tiempo y los demás lo requieran, serán objeto de liquidación de común acuerdo por las partes contratantes, procedimiento que se efectuará dentro del término fijado en el pliego de condiciones o términos de referencia o, en su defecto, a más tardar antes del vencimiento de los cuatro (4) meses siguientes a la finalización del contrato o a la expedición del acto administrativo que ordene su terminación, o a la fecha del acuerdo que la disponga. Y el artículo siguiente, 61 ibídem, sobre la liquidación unilateral, refiere a que si el contratista no se presenta a la liquidación o las partes no llegan a acuerdo sobre el contenido de la misma, será aplicada directa y unilateralmente por la entidad y se adoptará por acto administrativo motivado susceptible del recurso de reposición. Para la Sala la integración normativa hecha con respecto a esas tres disposiciones permite ver que la facultad del Estado para liquidar unilateralmente el contrato aparece frente al contratista particular marcada por los fines institucionales que debe cumplir "(...) y consiste en el poder de las entidades estatales de imponer coactivamente su voluntad sobre el contratista, durante la ejecución o liquidación del contrato, y en el deber de éste último de cumplir inmediatamente las obligaciones que le sean impuestas, sin perjuicio del derecho que le reconoce la ley de solicitar ante la jurisdicción de lo contencioso administrativa la nulidad de los actos y la reparación de los daños antijurídicos. Tal facultad administrativa se atribuyó al ADMINISTRADOR DE LO PÚBLICO y únicamente frente a su COLABORADOR PRIVADO y por lo mismo no para el contrato interadministrativo, en el cual ambas partes son Agentes Públicos, pues ambos representan la administración pública gestora del interés general y por lo tanto no imperan frente a éstas, en mundo negocial, los poderes coactivos, como así lo informa indirectamente el artículo 14 de la Ley $\mathrm{N}^{\circ}$ 80, 1993 que si bien alude a cláusulas excepcionales, ontológicamente se erige en canon ilustrativo de la prohibición del ejercicio de poderes unilaterales del Estado contratante respecto del Estado contratista".
} 
cláusulas o estipulaciones excepcionales" (Consejo de Estado, expediente 15.940, 2011). En

donde a su vez relaciona como cláusulas excepcionales al derecho común las de terminación, interpretación y modificación unilaterales y de caducidad ${ }^{55}$.

De acuerdo con la posición sostenida en el Concepto $\mathrm{N}^{\circ} 1230$ del (Consejo de Estado,1999) una interpretación finalista del Estatuto de Contratación Administrativa, y de las normas del derecho común, no permite aceptar a la luz de la lógica jurídica, que un contrato quede sin posibilidad de liquidarse y de conocerse la realidad económica de los extremos contratantes, por lo menos antes del vencimiento del término de caducidad de la acción contractual respectiva. $^{56}$

Se debe recordar que el vencimiento de los términos indicados en la ley trae consecuencias para los servidores públicos responsables, pero no lleva a la imposibilidad de lograr certeza en las obligaciones mutuas derivadas del convenio, las cuales deben quedar precisadas en el acta de liquidación ${ }^{57}$.

De no haberse realizado la liquidación pactada en dichos términos, ello no es óbice para

\footnotetext{
${ }^{55}$ Finalmente la Sala debe hacer notar que existe otro supuesto particular de exigibilidad de la garantía única de cumplimiento, amparado en el artículo 61 de la Ley $N^{\circ} 80,1993$, el cual dispuso la facultad para que las entidades estatales contratantes puedan expedir el respectivo acto administrativo motivado mediante el cual dispongan directa y unilateralmente la liquidación de los contratos estatales, en los casos en que no se logre la liquidación bilateral prevista en el artículo 60 ibídem, norma que permite a las entidades estatales establecer el balance final de liquidación y, por ello, determinar unilateralmente los saldos que resulten a cargo del contratista. Esa disposición debe leerse en concordancia con el artículo 68 del Código Contencioso Administrativo que facultó a las entidades estatales para constituir un título ejecutivo integrado por el acto de liquidación final del contrato y las correspondientes póliza de seguro, sin perjuicio de recordar en este punto que para su cobro se debía acudir a la Jurisdicción de lo Contencioso Administrativo, en cuanto la Ley $\mathrm{N}^{\circ}$ 80,1993, asignó la competencia a la mencionada jurisdicción, hasta la modificación introducida por la Ley N 1150, 2007 (Gómez, 2014).
}

${ }^{56} \mathrm{El}$ (Consejo de Estado, expediente 32797, 2015) ha señalado lo siguiente frente a las liquidaciones unilaterales en los contratos interadministrativos:

"En lo relativo a la competencia temporal de la administración para liquidar los contratos estatales, conforme a lo previsto en los artículos 60 y 61 de la Ley $\mathrm{N}^{\circ} 80,1993$ con la reforma introducida por la Ley $\mathrm{N}^{\circ} 446,1998$, se tiene que una vez vencido el plazo contractual la administración dispone de 4 meses para efectuar la liquidación bilateral, en caso de no realizarse así tiene 2 meses más para hacerlo unilateralmente y en el evento en que así no lo hubiere hecho, podrá intentarla hasta antes de que transcurra el término de 2 años más para que opere la caducidad de la acción contractual. Y esto es así aún en el caso de los contratos interadministrativos, pues la liquidación unilateral del contrato es una facultad legal pero no de aquellas que implican el ejercicio de una potestad exorbitante ya que la Ley $\mathrm{N}^{\circ} 80,1993$ en ninguna parte la enlista como tal".

\footnotetext{
${ }^{57}$ Para el caso de los convenios el Concepto 22859 expedido por la Secretaria General de la Alcaldía mayor de Bogotá manifiesta lo siguiente: En los Convenios Interadministrativos ambas partes son Agentes Públicos, que representan la administración pública gestora del interés general, no imperando frente a éstas los poderes coactivos o el ejercicio de poderes unilaterales del Estado contratante respecto del Estado contratista, habiéndose pactado la liquidación de los mismos, ésta deberá realizarse en las condiciones estipuladas.
} 
que en caso de que una de las partes considere procedente el reconocimiento de alguna obligación que haya quedado pendiente en el marco del desarrollo del Convenio lo haga, bien de manera concertada, vía conciliación o, bien sea de manera unilateral, mediante un acto administrativo fundamentado en el principio de responsabilidad y el reconocimiento de obligaciones naturales para el cumplimiento de obligaciones derivadas del Convenio que a su terminación no se hayan cumplido, teniendo en cuenta que si bien por regla general no se convienen obligaciones sinalagmáticas, puede ocurrir que por las características especiales en que se desarrolla el Convenio, se hayan generado obligaciones que estén aún pendientes. Puesto que hay casos en los que alguna de las entidades, no obstante puede haber cumplido con el objeto pactado, necesita cumplir compromisos que debe satisfacer con cargo a sus apropiaciones ${ }^{58}$.

\subsection{Casos de liquidaciones de contratos interadministrativos, con cláusulas y sin ellas,}

\section{desde el año 2014 al 2017.}

De los casos que se resaltan, se puede concluir que entre las vigencias señaladas, no hay una clara posición de las entidades estatales frente a la utilización de la figura de la liquidación unilateral de los contratos interadministrativos. En algunos casos solo se estipula la obligatoriedad liquidar de común acuerdo, así como en otros casos se deja estipulado en el contrato que se puede hacer la liquidación bilateral y que, agotado este procedimiento sin que hubiere resultado alguno, se puede hacer la liquidación unilateral. De manera que frente a esta situación donde también se han puesto en evidencia cambios continuos de la jurisprudencia del Consejo de Estado, y la no regulación por parte del legislador de forma expresa sobre la posibilidad de liquidar unilateralmente los contratos es que se presentan situaciones en los contratos que se destacan dentro de este trabajo de investigación.

\footnotetext{
${ }^{58}$ Concepto 22859 de 2012 Secretaría General, Alcaldía Mayor de Bogotá, Solicitud de concepto sobre liquidación de Convenios Interadministrativos.
} 
Se analizaron algunos casos presentados de forma aleatoria en entidades del orden nacional, en el que se evidencia las diferentes posturas tomadas por las entidades públicas al no tener en la legislación colombiana una norma clara y expresa sobre la utilización de la citada figura.

1. Contrato Interadministrativo 998 de 2014 suscrito entre la Superintendencia de Notariado y Registro y la Universidad Nacional de Colombia, cuyo objeto es contratar con un operador para el diseño y ejecución de las actividades del concurso público y abierto para el nombramiento de notarios en propiedad e ingreso a la carrera notarial, a saber: inscripción, evaluación y selección de los aspirantes a ser nombrados notarios en propiedad mediante concurso público y abierto, incluyendo la citación, gestión del concurso y publicación de resultados vía web y la calificación de las pruebas de conocimientos del concurso, las que se realizarán en los 5 nodos escogidos para tales efectos: Bogotá, Cali, Medellín, Barranquilla y Bucaramanga, así como el diseño de la entrevista, el análisis y calificación de los méritos y antecedentes de los concursantes, la conformación de las correspondientes listas elegibles y la respuesta a las reclamaciones, peticiones, recursos y acciones judiciales, que pudieran derivarse en relación con el trámite del concurso notarial, actividades que serán realizadas por el contratista, bajo los parámetros directrices y lineamientos establecidos y predeterminados por la Superintendencia de Notariado y Registro y el Consejo Superior. El cubrimiento del proceso deberá abarcar los 32 departamentos de Colombia.

Cuantía a contratar \$ 4.997’320.000 millones de pesos colombianos

Plazo de ejecución: 12 meses

Observación: En el contrato solo se estipula que se hace liquidación del contrato interadministrativo de común acuerdo dejando de lado la liquidación unilateral. 
2. Contrato Interadministrativo 107 de 2014 suscrito entre el Consejo Superior de la Judicatura y la empresa UNEEPM Telecomunicaciones cuyo objeto es establecer el marco por medio del cual UNEEPM Telecomunicaciones desarrollará proyectos de tecnología, telecomunicaciones, informática y TIC que incluya entre otros el análisis, diseño, desarrollo, implementación, administración, soporte y mantenimiento de soluciones informáticas, entrega de equipos, personal especializado y demás servicios que se requieran para cubrir los requerimientos que en esta materia tenga el Consejo Superior entre otras actividades que se concretarán a través de actas de ejecución o acuerdos específicos que hacen parte integral del presente contrato interadministrativo.

Cuantía a contratar \$18.038'960.587millones de pesos colombianos

Plazo de ejecución: 328 días

Observación: En el contrato solo se estipula que se hace liquidación del contrato interadministrativo de común acuerdo dejando de lado la liquidación unilateral.

3. Contrato Interadministrativo 560 de 2014 suscrito entre el Ministerio de Ambiente y Desarrollo Sostenible y la Empresa de telecomunicaciones de Bogotá S.A. E.S.P. cuyo objeto es establecer el marco por medio del cual Empresa de telecomunicaciones de Bogotá S.A. E.S.P. desarrollará proyectos de tecnología, telecomunicaciones, informática y TIC.

Cuantía a contratar \$ 1.044’118.817millones de pesos colombianos.

Plazo de ejecución: 559 días.

Observación: En el contrato se estipula que se hace liquidación del contrato interadministrativo de común acuerdo y/o liquidación unilateral en la cláusula séptima. 
4. Contrato Interadministrativo 1665 de 2015 suscrito entre ICBF y Servicios Postales Nacionales S.A. cuyo objeto es contratar el servicio integral de correo, mensajería y demás envíos postales que se generan en el Instituto Colombiano de Bienestar Familiar.

Cuantía: \$ 9.486’620.869 millones de pesos colombianos.

Plazo de ejecución: Hasta junio de 2018 o hasta agotar recursos.

Observaciones: Frente a este caso en la cláusula vigésima tercera del contrato citado se advierte que la liquidación se hace solo de común acuerdo.

5. Contrato Interadministrativo 3024 de 2015 suscrito entre el Ministerio de Cultura y la Financiera de Desarrollo Territorial S.A. - Findeter en el que la Financiera de Desarrollo Territorial S.A. - Findeter se compromete con el Ministerio a realizar la asistencia técnica y administración de recursos para la intervención de la casona y el trapiche de la Hacienda Cañasgordas, localizados en Cali, Valle del Cauca de conformidad con los estudios y diseños técnicos autorizados por el Ministerio de Cultura, y en cumplimiento del plan especial de manejo y protección autorizado mediante resolución N 0423 del 18 de enero de 2014.

Cuantía: \$1.900’000.000 millones de pesos colombianos

Plazo de ejecución: 823 días

Observaciones: Frente a este caso en la cláusula vigésima sexta del contrato citado no advierte si la liquidación se hace de común acuerdo o unilateralmente. De hecho el contrato se puede evidenciar, según el SECOP, no se ha liquidado.

6. Contrato interadministrativo $\mathrm{N}^{\circ} 04$ de 2016 suscrito entre la Dirección General de la Policía Nacional (PONAL) y la Corporación de la Industria Aeronáutica Colombiana S.A - 
CicaS.A. cuyo objeto es: Adquisición de repuestos aeronáuticos para las líneas: bell, (206, 407, 212 y 412), cessna, (152, 172, 206 y 208), hughes, twin otter, dc3-tp, beechcraft, (c99, b-1900, sk 200, sk 300 y sk 350), dash-8, atr-42, c26 y piper pa-31, pertenecientes a la Policía Nacional, Dirección de Antinarcóticos.

Cuantía: \$16.262’215.472 millones de pesos colombianos.

Plazo de ejecución: 207 días.

Observaciones: Frente a este caso en la cláusula vigésima quinta, correspondiente a la liquidación, del contrato citado, se consagra la posibilidad de liquidar de conformidad con lo señalado en los artículos 60 de la Ley $N^{\circ} 80,1993$ y artículo 11 de la Ley $N^{\circ} 1150,2007$.

7. Contrato interadministrativo $N^{\circ} 252$ de 2017 suscrito entre el Departamento Administrativo para la Prosperidad Social (DPS) y la Sociedad Hotelera Tequendama S.A, cuyo objeto es la prestación de servicios de apoyo logístico en la organización y realización de espacios de participación, eventos de capacitación, sensibilización, divulgación, socialización e implementación de las diferentes iniciativas, estrategias y programas desarrollados por el Departamento Administrativo para la Prosperidad Social (DPS).

Cuantía: \$ 7.123’658.625 millones de pesos colombianos.

Plazo de ejecución: 10 meses.

Observaciones: Frente a este caso en la cláusula décimo segunda del contrato citado se advierte que se efectuará la liquidación de acuerdo con el artículo 11 de la Ley $\mathrm{N}^{\circ} 1150,2007$, de 
lo cual se puede inferir que la liquidación del contrato podría darse por liquidación bilateral o unilateral.

8. Contrato interadministrativo $\mathrm{N}^{\circ} 01$ de 2017 suscrito entre el Congreso de la República y Radio Televisión Nacional de Colombia - RTVC, cuyo objeto es la prestación de los servicios de pre-producción, producción y post-producción de productos audiovisuales.

Cuantía: \$ 1.102’607.613 millones de pesos colombianos.

Plazo de ejecución: 222 de días.

Observaciones: Frente a este caso en la cláusula décimo novena del contrato citado se consagra la posibilidad de liquidar de conformidad con lo señalado en los artículos 60 de la Ley $\mathrm{N}^{\circ} 80,1993$ y artículo 11 de la Ley $\mathrm{N}^{\circ} 1150$ de 2007.

Así las cosas, después de los diferentes cambios de posiciones del Consejo de Estado, que ampliamente se han señalado en este trabajo, se puede concluir que después de haber adoptado ya una posición en la que no equipara la liquidación unilateral a un poder unilateral de la administración o, mejor dicho, a una cláusula exorbitante, se ha podido evidenciar que las entidades del Estado han estipulado en los contratos interadministrativos la posibilidad de liquidar unilateralmente en los casos que se ameriten. 


\section{CONCLUSIONES}

Frente a la liquidación unilateral de los contratos interadministrativos de los interrogantes que motivaron la investigación, se deriva la posición disímil en sentencias del Consejo de Estado, en las que las cláusulas exorbitantes se equiparan con la liquidación unilateral al definirla como un poder unilateral que no podría ser utilizada por la administración (Consejo de Estado, expediente 25.154. 2004). De ahí que después de analizar la génesis del instrumento jurídico ibídem, recorrer desde la generalidad a lo específico, resaltar las condiciones y las limitaciones de la utilización de la liquidación unilateral, revisar específicamente y en particular los aportes que podría hacer la legislación ecuatoriana en la solución del problema jurídico y revisar algunos casos de entidades públicas donde se evidencia que en la minuta de los contratos se presentan posiciones disímiles al incorporar la liquidación unilateral, se puede llegar a las siguientes conclusiones sobre el debate:

1. Lo primero que se podría resaltar es que la aplicación de las cláusulas excepcionales que tienen las entidades públicas para mitigar situaciones que afectan la prestación del servicio y, por consiguiente, el interés público, solo se circunscriben a las taxativamente señaladas en la Ley $\mathrm{N}^{\circ} 80,1993$, es decir las cláusulas exorbitantes consagradas en los artículos 14 al 19 del estatuto de contratación, esto según la jurisprudencia reciente (Consejo de Estado, expediente 32797, 2015) y la doctrina.

2. Para el caso en concreto de los contratos interadministrativos, se puede inferir, según lo dispuesto en la Ley $\mathrm{N}^{\circ}$ 80, 1993, que el legislador restringió la aplicación de las cláusulas exorbitantes, entre otras, teniendo en cuenta el criterio orgánico, al determinarse que los dos sujetos procesales son entidades del Estado que gozan de igualdad de condiciones y de las 
mismas prerrogativas que otorga la ley en la utilización de las cláusulas ibídem. Así mismo para dar aplicación a estas cláusulas, el legislador y según el desarrollo jurisprudencial de las sentencias del Consejo de Estado, referenciadas, estudiadas y analizadas en este trabajo, se concluye que no se pueden utilizar arbitrariamente, manteniendo algunos límites y condiciones para la utilización.

3. La liquidación unilateral de los contratos interadministrativos tiene como objetivo tomar decisiones respecto a los resultados y las obligaciones contraídas en el contrato estatal, sin necesidad de contar con la voluntad o con el consentimiento del respectivo contratista, después de haber intentado un acuerdo, y que el mismo haya sido fallido.

4. Frente a la responsabilidad atribuible al servidor público por no liquidar unilateralmente un contrato estatal en una etapa post-contractual, llama la atención el articulo 61 de la Ley 80 de 1993, reformado por el artículo 32 de la Ley 1150 de 2007, en el que consagra el deber funcional del servidor, después de agotado la liquidación bilateral, para que de manera independiente, mediante acto administrativo finiquite y concluya lo que haya lugar de la relación contractual. De manera tal, que si es un deber del funcionario responsable, y existe una obligación constitucional y legal expresa, como lo establece el articulo 267 de la Constitución Política y en los artículos 26 y 51 de la Ley 80 , que obliga a buscar el cumplimiento de los fines de la contratación so pena de responder disciplinaria, civil y penalmente por sus acciones y omisiones en la actuación contractual. Queda el interrogante si cabría la responsabilidad del servidor público, si para el caso en concreto de las liquidaciones unilaterales en los contratos interadministrativos se abstiene de hacerlo.

5. Ya en concreto, frente a las posturas jurisprudenciales del Consejo de Estado que llevaron a plantear el problema jurídico para el presente trabajo de investigación, se destaca la 
sentencia (Consejo de Estado, expediente 25.154, 2004) en la que se sostuvo una postura controvertida al equiparar la liquidación unilateral de los contratos interadministrativos a las cláusulas excepcionales; se desarrolla una teoría de integración armónica entre los artículos 14, 60 y 61 de la Ley $N^{\circ} 80,1993$, y de esta forma se restringe en los contratos interadministrativos la liquidación unilateralmente, se equipara a poderes excepcionales, al señalar que tanto el contratante como el contratista son sujetos públicos, con una relación horizontal de la Administración Estado que impide, de naturaleza, la imposición de decisiones unilaterales en el mundo de los negocios jurídicos a la contraparte que también es Estado. Sin embargo, años mas tarde el Consejo de Estado planteó una postura diferente que es objeto de discusión en este trabajo de investigación y se puede entender que la liquidación unilateral en los contratos interadministrativos es posible en la medida en que no son una potestad exorbitante ni un poder unilateral caprichoso de la administración, aun cuando se está entre sujetos contractuales iguales, sino que se circunscribe a una herramienta jurídica post-contractual que tiene como fin hacer un balance y un ajuste de cuentas en la ejecución del contrato estatal tal y como lo señala el (Consejo de Estado, expediente 32797, 2015) al advertir que en el caso de los contratos interadministrativos, la liquidación unilateral del contrato es una facultad legal pero no de aquellas que implican el ejercicio de una potestad exorbitante ya que la Ley 80 de 1993 en ninguna parte la en lista como tal.

6. Frente al valioso aporte del análisis legislativo comparado de liquidaciones unilaterales en los contratos interadministrativos en la República de Ecuador, bajo la metodología de la escuela alemana juscomparatista, se pudo reconocer el sistema normativo y los procedimientos adoptados entorno al problema de la investigación planteado, se llevó a cabo una breve descripción sobre las instituciones jurídicas vinculadas con la comparación, se constataron 
algunas semejanzas y diferencias en cuanto a los contratos interadministrativos y las liquidaciones unilaterales, así como se pudo concluir la pertinencia de la citada legislación, en la medida que aporta una solución al problema jurídico planteado, al aplicar la norma general con la que se liquidan unilateralmente los contratos estatales, bajo el mismo procedimiento para el caso de los contratos interadministrativos, sin perjuicio, que al mismo nivel estén dos entidades públicas en calidad de contratante y contratista.

7. Después de traer a colación algunos casos que en la práctica demuestran cómo las entidades públicas del orden nacional, entre el 2014 a 2017, están procediendo con la liquidación unilateral en los contratos interadministrativos; se logra evidenciar las diferentes posturas tomadas por las entidades estatales, en donde la regla general es excluir y no introducir para esta tipología de contrato la opción de liquidar unilateralmente el contrato interadministrativo.

8. Es necesario que se unifique una posición del órgano de cierre de la jurisdicción de lo contencioso administrativo frente a la liquidación unilateral de los contratos interadministrativos teniendo en cuenta que el legislador colombiano no dejó taxativamente señalado que las cláusulas exorbitantes solo se circunscribían a las reguladas en la Ley $\mathrm{N}^{\circ} 80,1993$. Tampoco se reguló con claridad la liquidación unilateral, que no se podría interpretar como una potestad unilateral que tienen las entidades públicas y así mismo no se configura como una potestad exorbitante. De ahí que el Consejo de Estado haya tenido posturas que no han sido pacíficas frente a la utilización de esta herramienta para finiquitar los contratos interadministrativos.

9. Finalmente, otra opción es que se legisle tomando la referencia normativa ecuatoriana en donde el procedimiento y el marco de acción del contratista público y el privado es igual. Es decir, que el régimen previsto para la administración, terminación, recepción y liquidación de 
todo tipo es el mismo, de ahí que a la entidad pública contratista no se le reconozcan prerrogativas por el hecho de estar en igualdad de condiciones en la relación contractual. 


\section{Bibliografía}

1) Aguirre Torres, M. (2016) Manual de prácticas de derecho administrativo. LojaEcuador.

2) Arango Betancourth, J. C., \& García Moncada, J. G. (2004). Aplicación de las cláusulas exorbitantes en los contratos estatales regulados por regímenes especiales. Bogotá D.C.: Pontificia Universidad Javeriana Facultad de Ciencias Jurídicas.

3) Baldeón, Carlos. (2008). La Normalización como pilar innovador de la Contratación Pública. Ecuador: Universidbogoad Andina Simon Bolivar.

4) Baldeón B, I. M. (2014). La Libertad de Empresa y el Derecho de la Competencia en el marco de la Contratación Pública del Ecuador. Tesis Doctoral, Universidad Castilla- la Mancha.

5) Baldeón B, I. M. (2016). El régimen interadministrativo en la contratación pública del Ecuador y su análisis en el derecho comparado. Revista de la Escuela Jacobea de Posgrado $N^{o} 10$, junio 2016, , págs. 49-78.

6) Benavides, J. L. (2004) El contrato estatal entre el derecho público y el derecho privado. Bogotá, D.C. Universidad Externado de Colombia.

7) Bohórquez Z, L. (2002) El contrato de Concesión. Bogotá, D.C. Universidad Javeriana de Colombia.

8) Carvajal, Lizardo (2015), Metodología de la Investigación, Bogotá, Editorial FAID.

9) Celis Danzinger, G., \& BARRA GALlARDO, N. (2010). Curso de Derecho Administrativo. Santiago: Thomson Reuters Punto Lex,. 
10) Cita vargas, V. P. (2016). Importancia de la liquidación de los contratos estatales con relación a las obligaciones que se derivan de ella. Bogotá, Colombia: Universidad Militar Nueva Granada.

11) Coecha Leon, Cesar Antonio. (2015). Declaración de siniestros en la contratación pública colombiana: construcción dogmática de una regulación inconclusa. Getafe: Universidad Carlos III de Madrid.

12) Comadira, R. J. (2010). Las Contrataciones Interadministrativas y el Principio de la Libre Elección Tomo 119. Buenos Aires, Argentina: El Derecho.

13) Charris Benedetti, Juan Pablo; Llamas Foliaco, Alfonso Carlos, (2016) El riesgo inherente al proveedor como criterio preventivo en la contratación pública, Bogotá: Revista Derecho del Estado.

14) Chevallier, J. (2003) L' etat postmoderne. París. LGDJ.

15) Chávez Marín, A. R. (2012). Los convenios de la Administración: entre la gestión. Bogotá, Colombia: Universidad del Rosario.

16) Dávila Vinueza, L. G. (2003). Régimen Jurídico de la Contratación Estatal. Segunda Edición. . Bogotá, Colombia: Legis Editores.

17) Dávila Vinuenza, L. G. (2016). Régimen Juridico de la Contratación Estatal. Bogotá, Colombia: Legis.

18) De la Puente y Lavalle, Manuel. (1998) “Cláusulas Exorbitantes”. Themis Revista de Derecho, ISSN 1810-9934, No 39.

19) Diez, Manuel Maria, (1965). Derecho Administrativo Tomo II. Buenos Aires, Argentina. Omeba.

20) Díaz, C. (2013). La liquidación. Medellin: Librería Juridíca Sanchez. 
21) Eco, Humberto (1998) Como se hace una tesis. México: Editorial Gedisa.

22) Escóla, Héctor Jorge, (1979) Tratado Integral de los tratados interadministrativos, parte especial, Vol II Ediciones Depalma.

23) Estrada Sánchez, J. P. (2009). Contratación directa, convenios interadministrativos y contratos y contratos de cooperación internacional. En Contratación estatal: estudios sobre la reforma del estatuto contractual Ley 1150 de 2005. Bogotá: Universidad Externado de Colombia.

24) Escobar Gil, R. (2003). Teoría General de los Contratos de la Administración Pública, Primera edición. Bogotá: Legis.

25) Escola, H. J. (1979). Tratado Integral de los tratados Interadministrativos, parte especial, Vol II. Buenos Aires: Ediciones Depalma.

26) Expósito Velez, J. C. (2013). Forma y contenido del contrato estatal. Bogotá, Colombia: Universidad Externado.

27) Merryman, John Henry (2011). Fines, Objeto y Método del Derecho Comparado Universidad de Stanford, traducido por Rodríguez,-Fausto E (2011) México; Editorial: Universidad Autónoma de México. Artículo Revista jurídica de la UMAN - 1170.

28) Foillard, F. (2004). Droit Administratif, Armand Colin. Paradigme Publicatios Universitaires , 216.

29) Gasman, G. (1937). Teoría de la Imprevisión y los Contratos Administrativos. Talleres Gráficos Gutenberg.

30) Gaston, Jese (1949), "Principios Generales del Derecho Administrativo" Tomo III, Buenos Aires:Depalma. 
31) Garcia De Enterria, E. y. (2000). Tratado de Derecho Administrativo. Madrid, España: Civitas.

32) Garrido Falla, Fernando. (2010) Tratado de Derecho Administrativo. Madrid, España: Editorial Tecnos S.A.

33) Gibert, P. (1995) Managment public, managment de la pusissance publique en F. Lacasse, J. C,; Thoening, L' action publique. París. L’Harmattan.

34) Güecha Medina, Ciro Nolberto, (2006). Falacia de las cláusulas exorbitantes en las Contratación Estatal. Medellin: Facultad de Derecho de la Universidad de Medellin.

35) Gutiérrez Rey, D. C. (2015). La inexistencia de la reversión presunta. Bogotá: Universidad Militar Nueva Granada.

36) Hebe, Beatriz; LOPEZ; Banti, Liliana Esther; Muñoz, Jorge; Rubins, Roxana. (Noviembre de 2012). Un nuevo resurgir de la contratación interadministrativa. El Observatorio de Políticas Públicas del Cuerpo de Administradores Gubernamentales , 19.

37) Herrera Barbosa, B. H. (2003). Contrato, Convenios y Actos Consensuales. Medellin: Ediciones Juridícas Gustavo Ibañez Ltda.

38) Hernández Silva, Aida Patricia,(2009) La liquidación del Contrato Estatal, Revista digital de Derecho Administrativo, Universidad Externado de Colombia.

39) Ibáñez Najar, J. E. (2007). Estudios de derecho constitucional y administrativo. Bogotá: Legis Justicia y Desarrollo Sostenible y la Universidad Sergio Arboleda.

40) Iribarren, J. A. (1940). Lecciones de Derecho Administrativo, Tomo I, . Santiago, Chile : Nacimiento.

41) III, R. P. (2004). Un posible retroceso en la contratación pública”. Buenos Aires, Argentina: Jurisprudencia Argentina. 
42) Jiménez Blanco, A. (2002). Manual de Derecho Administrativo. Madrid, España: Tiran lo Blanch.

43) Lamprea Rodríguez, P. A. (2007). Contratos Estatales. Bogotá, Colombia: Temis.

44) Matallana Camacho, E. (2013) Liquidación Unilateral de los Contratos Interadministrativos. Obtenido el 25 de mayo de 2017, de http://matallanaabogadosconsultores.com/

45) Marienhoff, M. (1962). Administración pública - Actividad Inter- Orgánica. Relaciones Interadministrativas , 77.

46) Marienhoff, M. (1966). Tratado de derecho Administrativo (3 Ed). Buenos Aires: Abeledo - Perrot.

47) Marienhoff, M. (1970). Tratado de derecho Administrativo. Buenos Aires: Abeledo Perrot.

48) Merino, E. (1936). Derecho Administrativo, apuntes,. Santiago: Imprenta Universitaria. 49) Molano López, M. R. (2009). a nueva estructura de los procesos selectivos en la contratación estatal. Bogotá: Ediciones nueva jurídica.

50) Mutis Vanegas, A. y. (2001). La contratación estatal: análisis y perspectivas. Bogotá: Universidad Javeriana.

51) Moraga Klenner, C. (2010). Tratado de Derecho Administrativo; La Actividad Formal de la Administración del Estado (2). Santiago: Abeledo Perrot - Legal Publishing.

52) Moraga Klenner, C. (2010). Tratado de Derecho Administrativo. Santiago.

53) Moreno García, V. d. (2011). Contratación Pública y Modernización del Estado Los Contratos Interadministrativos. Quito: Universidad Andina Simón Bolívar Sede Ecuador. 
54) Mutis Vanegas, A. Quintero Munera, A. (2000). La Contratación Estatal: Análisis y Perspectivas. Bogotá: Universidad Javeriana Sede Bogotá.

55) Muller, P. (2010) Las políticas públicas. Bogotá, D.C. Universidad Externado de Colombia.

56) Niño Zambrano, A. (2011) Contratación estatal delimitación: cláusulas excepcionales en contratos estatales. Bogotá. D.C. Editorial Universidad de la Sabana.

57) Ospina Fernández, G (2010). Teoría general del contrato y de los demás actos y negocios juridicos. Bogotá: Editorial Temis.

58) Palacio Hincapié, J. Á. (2010). La contratación de las entidades estatales. Medellin: Librería Jurídica Sánchez R. Ltda.

59) Pantoja Bauzá, R. R. (2010). Tratado de Derecho Administrativo. Derecho y Administración del Estado (4), T. I,. Santiago: Legal Publishing,.

60) Parra Sanhueza, A. B. (2013). Qué entender por contrato administrativo en el ordenamiento jurídico chileno actual? (U. D. PÚBLICO, Ed.) Santiago: Universidad de Chile.

61) Pemberthy López, P. L. (2015). La liquidación de los Contratos Estatales. Revista de la facultad de derecho y ciencias politicas - UPB , 427.

62) Perdomo Guerrero, C. E., \& Malagón Pinzón, M. A. (2014). Los convenios de la administración y los contratos estatales: conceptos diferentes con regímenes jurídicos distintos. Bogotá: Universidad de los Andes.

63) Pérez Hualde, Alejandro, (2011) Exorbitancia de las prerrogativas de la administración en los contratos, México: Revista Ópera Prima de Derecho Administrativo No 9, Asociación Internacional de Derecho Administrativo. 
64) Pino Rucci, J. (. (2005). régimen jurídico de los contratos estatales. Bogotá: Universidad Externado de Colombia.

65) Poblete Vinaixa, J. (2009). Actos y Contratos Administrativos, 5ta Edición revisada y actualizada. (Legal Publishing, Ed.) santiago: Legal Publishing,.

66) Rengifo García, Ernesto (2014) Las Facultades Unilaterales en la Contratación Moderna, Bogotá: Editorial Legis.

67) Reyes Yunis, L. (. (2007). Reforma a la contratación estatal. Bogotá, Colombia: Universidad del Rosario.

68) Rico Puerta, L. A. (2013). Teoría General y Práctica de la Contratación Estatal. Bogotá: Leyer.

69) Rico Puerta, L. A. (2015). Teoría General y Práctica de la Contratación Estatal. Bogotá, Colombia: Leyer.

70) Rivero Ysern, E. (1980). Las relaciones interadministrativas. Revista de administración pública, España, 41.

71) Rocha Pereyra, G. (2004). "El Decreto 204/2004. Un posible retroceso en la contratación pública”. Tomo III. Buenos Aires, argentina: Jurisprudencia Argentina.

72) Rodríguez, M. (2013). Los contratos estatales en Colombia. . Medellin, Colombia: Juridíca Sanchez.

73) Santofimio Gamboa, J. O. (2011). Tratado de derecho administrativo, t. iV, Contratación indebida. Bogotá: Universidad Externado de Colombia.

74) Santos Rodríguez, J. E. (2010) La cláusula de reversión en los contratos de concesión administrativa. X Jornadas de Derecho Administrativo - Incertidumbre en la contratación estatal. Bogotá. Universidad Externado de Colombia. 
75) Santos Rodríguez, J. E. (s.f.). Consideraciones sobre los Contratos y Convenios Interadministrativos. Obtenido de Revista Universidad del Externado: http://revistas.uexternado.edu.co/index.php/Deradm/article/download/2592/2231.

76) Sayagues Laso, Enrique. (1998) Tratado de Derecho Administrativo, Tomo I. Uruguay: Fundación Cultura Universitaria.

77) Serna, Pedro y Toller, Fernando, (2000) La interpretación constitucional de los derechos fundamentales. Una alternativa a los conflictos de los derechos, Buenos Aires: La Ley.

78) Silva Cimma, E. (2001). Derecho Administrativo Chileno y Comparado, Actos, Contratos y Bienes. Santiago: Editorial Jurídica de Chile.

79) Suárez Beltrán, G. (2009). La nueva contratación pública en Colombia. Bogotá: Legis.

80) Subdirección General De Control, C. T. (2015). Manual de buenas prácticas en la contratación pública para el desarrollo del Ecuador. Ecuador: Superintendencia de control del poder de marcado.

81) Solano Sierra, Jairo Enrique. (1994). Contratación Administrativa, , Bogotá: Ediciones Librería Profesional.

82) Tapia Rosales, Stefani Lisset, (2013). La Contratación Pública en régimen especial con entidades del sector público de acuerdo al No 8 del artículo 2 de la Ley Orgánica de Contratación Pública. Ecuador: Universidad San Francisco de Quito.

83) Tamayo, Rolando. (2007). Teoría Jurídica y Derecho Comparado, México: Editorial: Universidad Autónoma de México.

84) Vedel, G. (1980). Derecho administrativo, Edición Española. Madrid: Aguilar.

\section{Leyes, Decretos y otras normas}


1) Colombia. Asamblea Nacional Constituyente. Constitución política colombiana (1991) Bogotá, D.C.

2) Colombia. Código Civil. (1873) Bogotá, D.C.

3) Colombia. Alcaldía Mayor de Bogotá. Secretaría General. (2012) Concepto 22859.

4) Colombia. Decreto Ley $\mathrm{N}^{\circ} 222,1983$, Por el cual se expiden normas sobre contratos de la Nación y sus entidades descentralizadas y se dictan otras disposiciones.

5) Constitución Política de 1991. (s.f.). Obtenido de http://www.alcaldiabogota.gov.co/sisjur/normas/Norma1.jsp?i=4125:

6) Decreto Ley 222 de 1983. (17 de 01 de 2017). Obtenido de http://www.creg.gov.co/html/Ncompila/htdocs/Documentos/Energia/docs/decreto_0222_19 83.htm

\section{Jurisprudencia del Consejo de Estado}

1) Colombia. Consejo de Estado. Sala de lo Contencioso Administrativo. Sección Tercera. De Greiff Restrepo, G. (1989) expediente 5.334.

2) Colombia. Consejo de Estado, Sala de Consulta y Servicio Civil. Suarez Hernandez, Daniel. (1997) radicación número: 10608.

3) Colombia. Consejo de Estado, Sala de lo Contencioso Administrativo. Sección Tercera. Hoyos Duque, Ricardo. (1998) radicación número: 11101.

4) Colombia. Consejo de Estado, Sala de Consulta y Servicio Civil. Daniel. (1999) Radicación número: 1230.

5) Colombia. Consejo de Estado, Sala de Consulta y Servicio Civil. Osorio Isaza, L. C. (2000) Radicación número: 1293. 
6) Colombia. Consejo de Estado. Sala de lo Contencioso Administrativo. Sección Tercera. Hoyos Duque, R. (2002) expediente 15.802.

7) Colombia. Consejo de Estado. Sala de lo Contencioso Administrativo. Sección Tercera. (2002) expediente 19.333.

8) Colombia. Consejo de Estado. Sala de Consulta y Servicio Civil. Sección tercera Trejos Jaramillo, A.(2003) Radicación 1453. expediente 23421.

9) Colombia. Consejo de Estado. Sala de lo Contencioso Administrativo. Sección Tercera. Giraldo Gómez, M. E. (2004) expediente 25.154.

10) Colombia. Consejo de Estado. Sala de lo Contencioso Administrativo. Sección Tercera. Saavedra, R. (2005) expediente 30114.

11) Colombia. Consejo de Estado. Sala de lo Contencioso Administrativo. Sección Tercera. Correa Palacio, S. (2008) expediente 16075.

12) Colombia. Consejo de Estado, Sala de lo Contencioso Administrativo. Sección Tercera, Fajardo Gómez, Mauricio. (2010) Expediente: 26101.

13) Colombia. Consejo de Estado. Sala de lo Contencioso Administrativo. Sección Tercera. Gil Botero, E. (2011) expediente 15.940.

14) Colombia. Consejo de Estado. Sala de lo Contencioso Administrativo. Sección Tercera. Gil Botero, E. (2013) expediente 24510.

15) Colombia. Consejo de Estado. Sala de lo Contencioso Administrativo. Sección Tercera. Rojas Danilo, R. J. (2014) expediente 28881.

16) Colombia. Consejo de Estado. Sala de lo Contencioso Administrativo. Sección Tercera. Pazos Guerrero, R. J. (2014) expediente 29028. 
17) Colombia. Consejo de Estado. Sala de lo Contencioso Administrativo. Sección Tercera. Valle de la Hoz, O. M. (2015) expediente 26.938.

18) Colombia. Consejo de Estado. Sala de lo Contencioso Administrativo. Sección Tercera. Santofimio Gamboa, J. O. (2015) expediente 32.797.

\section{Jurisprudencia de la Corte Constitucional}

1) Colombia. Corte Constitucional Sentencia C-316-1995 Barrera Carbonell, Antonio, (19 de julio de 1995).

2) Colombia. Corte Constitucional. Sentencia C-250. Herrera Vergara, H. (1996) expediente D-1064 (Escola, 1979).

3) Colombia. Corte Constitucional. Sentencia T-569/98 Beltrán Sierra, A. (1998) expedientes T-171.895 y T-176.175.

4) Colombia. Corte Constitucional. Sala octava de revisión. Tafur Galvis, A. (2001) expediente T-463.21.

5) Colombia. Corte Constitucional. Sentencia C-300/12. Pretelt Chalju, J. I. (2012) expediente D-8699.

6) Colombia. Corte Constitucional. Sentencia C-44214/14. Mendoza, G. (2012) expediente D-41239.

\section{Colombia Compra Eficiente}

1. Colombia Compra Eficiente. (2014) Consultado el 20 de mayo de 2017. Página web de $\begin{array}{lllll}\text { contratación } & \text { estatal } & \text { del } & \text { Gobierno }\end{array}$ Colombia:https://www.contratos.gov.co/consultas/detalleProceso.do?numConstancia=15$12-3415094$ 
2. Colombia Compra Eficiente. (2014) Consultado el 20 de mayo de 2017. Página web de $\begin{array}{lllll}\text { contratación } & \text { estatal } & \text { del } & \text { Gobierno }\end{array}$ Colombia:https://www.contratos.gov.co/consultas/detalleProceso.do?numConstancia=1412-3161495.

3. Colombia Compra Eficiente. (2014) Consultado el 20 de mayo de 2017. Página web de $\begin{array}{llll}\text { contratación } & \text { estatal del } & \text { Gobierno } & \text { Colombia: }\end{array}$ https://www.contratos.gov.co/consultas/detalleProceso.do?numConstancia=15-12-3310949. 4. Colombia Compra Eficiente. (2015) Consultado el 21 de mayo de 2017. Página web de $\begin{array}{lllll}\text { contratación } & \text { estatal } & \text { del } & \text { Gobierno }\end{array}$ Colombia:https://www.contratos.gov.co/consultas/detalleProceso.do?numConstancia=15$12-4544673$.

5. Colombia Compra Eficiente. (2015) Consultado el 21 de mayo de 2017. Página web de contratación estatal del Gobierno de Colombia: https://www.contratos.gov.co/consultas/detalleProceso.do?numConstancia=16-12-4598970. 6. Colombia Compra Eficiente. (2016) Consultado el 21 de mayo de 2017. Página web de $\begin{array}{lllll}\text { contratación } & \text { estatal } & \text { del } & \text { Gobierno }\end{array}$ Colombia:https://www.contratos.gov.co/consultas/detalleProceso.do?numConstancia=16$12-4832321$.

7. Colombia Compra Eficiente. (2017) Consultado el 21 de mayo de 2017. Página web de $\begin{array}{lllll}\text { contratación } & \text { estatal } & \text { del } & \text { Gobierno }\end{array}$ Colombia:https://www.contratos.gov.co/consultas/detalleProceso.do?numConstancia=17$12-6250698$. 
8. Colombia Compra Eficiente. (2017) Consultado el 24 de mayo de 2017. Página web de $\begin{array}{lllll}\text { contratación } & \text { estatal } & \text { del } & \text { Gobierno }\end{array}$ Colombia:https://www.contratos.gov.co/consultas/detalleProceso.do?numConstancia=17$12-6077610$ 